\title{
INVESTIGATION OF HYDROCARBON PHYTOREMEDIATION POTENTIAL OF LUPINUS CHAMISSONIS IN LABORATORY MICROCOSMS
}

\author{
Wendy Martin, M.S. \\ Yarrow M. Nelson, Ph.D. \\ Kenneth Hoffman, M.S. \\ Department of Civil and Environmental Engineering \\ California Polytechnic State University \\ San Luis Obispo, CA 93407
}

\begin{abstract}
Controlled laboratory microcosms were used to research the phytoremediation potential of lupines (Lupinus chamissonis) for hydrocarbon-contaminated groundwater at a former oil field near Guadalupe, California. During oil production in the Guadalupe Oil Field, a kerosene-like hydrocarbon mixture was used as a diluent to improve the flow of the heavy crude oil. Leaking tanks and pipes resulted in diluent contamination in the soil and groundwater. Native plant species were planted at a pilot-scale field site to investigate the feasibility of using phytoremediation to remediate the groundwater contamination. In the field, biological and hydrological factors make it difficult to determine the specific contributions of individual plant species to hydrocarbon degradation. To overcome the variability of the field site, laboratory experiments with plants grown in glass containers were conducted to examine and quantify the role of plants in contributing to hydrocarbon biodegradation. Earlier experiments, using Salix lasiolepis (Arroyo willows), indicated increased hydrocarbon biodegradation with willows present. Since L. chamissonis plants are a prevalent native species at the site, and because of their potential for nitrogen fixation, the present laboratory study was undertaken to evaluate the contribution of $L$. chamissonis to phytoremediation and to compare L. chamissonis and $S$. lasiolepis results. Hydrocarbon-contaminated groundwater from the field site with an initial total petroleum hydrocarbon (TPH) concentration of $5.5 \mathrm{mg} / \mathrm{L}$ was recirculated through 1-gallon glass soil chambers for 105 days under conditions mimicking site conditions. Chambers were established in triplicate with 1) soil with active bacteria and one L. chamissonis plant, 2) soil with active bacteria, and 3) sodium azide inhibited soil. Biodegradation was monitored using gas chromatography/mass spectrometry (GC/MS) to determine TPH concentrations on days 0,24 , and 105. TPH concentrations in the L. chamissonis and soil-only chambers were not significantly different from each other after 24 days, suggesting the L. chamissonis did not contribute to bioremediation under these conditions. After 105 days, the final TPH concentrations were $0.95 \pm 0.22$ for the sodium azide inhibited, $0.67 \pm 0.085$ for the soil only, and $0.33 \pm 0.12 \mathrm{mg} / \mathrm{L}$ for the $L$. chamissonis chambers. Thus, final residual TPH concentrations in the chambers planted with $L$. chamissonis were less than half of those in the soil-only chambers, and this difference was statistically significant at the $95 \%$ confidence level. These results are similar to those for the willows grown under the same conditions, indicating that the nitrogen-fixing ability of the lupines did not lead to enhanced bioremediation relative to willows. Nonetheless, this research shows that lupines enhance biodegradation, most likely by stimulating the hydrocarbon-degrading microorganisms in the soil. Since lupines easily establish themselves
\end{abstract}


at the site they are excellent candidates for use in ecological restoration and phytoremediation at the former Guadalupe Oil Field.

\section{INTRODUCTION}

\section{Former Guadalupe Oil Field}

The former Guadalupe Oil Field (GOF) covers approximately 2,700 acres and is located on the central coast of California. The former GOF is part of the Guadalupe-Nipomo Dune Complex and is one of the last intact dune systems in the state of California. Numerous threatened and endangered plants and animal species and various species of special concern inhabit the former GOF. Unocal Corporation produced oil at this site for over 40 years. Due to the nature of the site, numerous individual wells were required for production. The petroleum at the site was too viscous to be pumped, therefore a solvent was added to the oil to enable the oil to be pumped to the surface. The solvent was referred to as "diluent" due to it diluting the viscous crude oil. The diluent was derived from the distillation of crude oil at a nearby refinery and was similar to a mixture of kerosene and diesel oil, with an equivalent hydrocarbon range of $\mathrm{C}_{10}$ to $\mathrm{C}_{40}$ (Lundegard and Garcia, 2001). The majority of the diluent constituents have low water solubility. Diluent characteristics include: (1) equivalent carbon length of the diluent ranges from $<\mathrm{nC}_{10}$ to $>\mathrm{nC}_{30}$, (2) about $70 \%$ of the diluent falls in the diesel range of $\mathrm{nC}_{14}$ to $\mathrm{nC}_{22}$, and (3) the separate-phase diluent consists of saturated (41\%), aromatic (29\%), and polar compounds plus asphaltenes (30\%) ( Lundegard and Garcia, 2001).

The depth to groundwater ranges from 0 to 130 feet and fluctuates seasonally. Approximately 8 million gallons of diluent leaked from pipes, tanks, and fittings over the years resulting in substantial contamination of the Guadalupe site. Approximately 90 separate-phase and dissolved-phase diluent plumes were identified at the site. In the late 1990s, a remediation plan was developed and remediation began through the Guadalupe Restoration Project. The restoration activities include various approaches including new and innovative techniques. The applicability and feasibility of potential remediation technologies including phytoremediation, land treatment, bioremediation, biosparging, natural attenuation, and hot water and steam flooding are being evaluated through pilot studies. Minimizing disturbance to the valuable ecosystem at Guadalupe is an important consideration of the remediation effort. Excavation has been conducted on highly contaminated parts of the Guadalupe site leaving barren sites necessitating restoration and remediation for the remaining groundwater contamination.

\section{Phytoremediation}

Phytoremediation is an innovative technology utilizing various plants to degrade, extract, contain, or immobilize contaminants from soil and water. For removal of hazardous compounds, phytoremediation may be more cost-effective than alternative mechanical or chemical methods. Phytoremediation applications can be classified based on the fate of the contaminant and the mechanisms involved. The root zone influencing plants is known as the rhizosphere. Microbial degradation rates in the rhizosphere may be greater than in non-rhizosphere soils due to increased microbial counts in rhizosphere soils (EPA, 2000; Chaîneau et al., 2000; Günther et al., 1996; Lee and Banks, 1993). In the rhizosphere, bacteria live in colonies covering as much as 4 
to $10 \%$ of the plant root surface area (Schnoor et al., 1995). The ratio of the number of microorganisms in rhizosphere soil to the number of microorganisms in non-rhizosphere soil commonly ranges from 5 to 20 but can be as high as 100 or greater (Anderson et al., 1993). Increased microbial counts may be due to plant exudates, microbial or fungal symbiosis with the plant, or other influences of the root zone. The decay of fine root biomass adds organic carbon to the soil increasing microbial mineralization rates (Schnoor et al., 1995). Degradation may occur within certain plants through the plant metabolizing the available nutrients and in the process detoxifying the contaminant (EPA, 2000). Phytoremediation is most suited for sites with shallow contamination $(<5 \mathrm{~m}$ depth) of moderately hydrophobic pollutants or excess nutrients (Schnoor et al., 1995).

The possible phytoremediation mechanisms include phytoextraction, rhizofiltration, phytostabilization, rhizodegradation, phytodegradation, and phytovolatilization (EPA, 2000). Rhizodegradation, is the degradation of an organic contaminant in soil through microbial activity enhanced by the presence of the root zone. The presence of root exudates increases microbial populations and activity in the rhizosphere increasing organic contaminant biodegradation (Anderson et al., 1993; EPA, 2000). Physiochemical and biological treatments involving microorganisms are effective for the remediation of hydrocarbon contaminated soils (Chaîneau et al., 2000). Plant roots can enhance soil conditions through increasing soil aeration and moderating the soil moisture content. This can create conditions more favorable for biodegradation. Rhizodegradation is primarily soil-based, but groundwater treatment may be induced through plant transpiration bringing contaminants into the root zone through soil suction. Rhizodegradation was the only mechanism expected for diluent remediation due to (1) phytoextraction, rhizofiltration, and phytostabilization not being effective for remediating organic contamination (EPA, 2000), (2) the $\log \mathrm{K}_{\text {ow }}$ of diluent is higher than the range (0.5 to 3.5) for compounds readily absorbed by plants (Van der Lelie et al., 2001), (3) compounds having $\log \mathrm{K}_{\mathrm{ow}}$ values less than 3.5 are $<\mathrm{C}_{9}$ (Gustafson et al., 1997), while diluent is $\mathrm{C}_{10}$ to $\mathrm{C}_{40}$ (Haddad and Stout, 1996), (4) small and low molecular weight polar compounds are usually favored for plant absorption, while large and high molecular weight lipophilic compounds (similar to diluent) are usually excluded from the root (Anderson et al., 1993) and (5) prior research using diluent and willows demonstrated no phytovolatilization of diluent constituents (Elliot, 2002).

Phytoremediation, utilizes various plants to degrade, extract, contain, or immobilize contaminants from soil and water, and is an attractive remediation option due to its limited adverse impact on the ecosystem. Phytoremediation can be used in conjunction with revegetation for restoration of excavated sites. This combined remediation and restoration approach has been termed "ecoremediation" by the Environmental Biotechnology Institute (EBI) at California Polytechnic State University, San Luis Obispo (Cal Poly).

\section{Guadalupe Phytoremediation Field Studies}

Two areas at Guadalupe are currently being used for phytoremediation pilot field studies. At area O13, Arroyo willows and black cottonwoods were planted in rows similar to an orchard in attempts to remediate diluent contaminated groundwater. Increased numbers of bacteria were present in more contaminated areas. The second pilot study was initiated in 1999 as an ecoremediation approach to restore the natural ecosystem while remediating the contaminated 
groundwater. This study is being conducted at site C8 at Guadalupe and the goal is to establish a healthy, self-sustaining community compatible with neighboring natural habitats. Three areas were planted with various mixtures of phreatophytic trees, shrubs, and herbs native and indigenous to the area. The plots were high, moderate, and low diversity and a fourth plot acts as the control. Dune lupines were not initially planted at this site, but are one of the dominant native species present. The groundwater flow rate at this site is approximately 1 foot per day (Hoffman, 2003). Increased microbial counts occurred in the higher diversity planting areas and aerobic metabolism predominates at the site (EBI, 2003). Field studies are valuable in testing new technologies. However, the exact mechanisms operating due to the technology being tested are hard to separate from the influences of other variables in the field. Controlled laboratory studies enable actual mechanisms to be more easily distinguished.

\section{Cal Poly Phytoremediation Project}

Unocal has funded phytoremediation laboratory studies by providing grants through EBI at Cal Poly. The phytoremediation grant has funded undergraduate and graduate research projects. The goal of the overall phytoremediation project is to determine the effectiveness of phytoremediation at the Guadalupe site.

For her undergraduate senior project at Cal Poly, Sandy Scott designed laboratory growth chambers to measure the ability of native Guadalupe plants to contribute to the remediation of the diluent contamination. Scott based her design on a design reported by Orchard and Doucette (2000) for use with trichloroethylene (TCE). Scott's design consisted of two spinner flasks sealed together to keep the upper foliar chamber separate from the lower root chamber. Spinner flasks were used to allow air and water to be circulated through each chamber (Scott, 2001). Keith Elliot used Scott's design for his Cal Poly Master's thesis experiment. Elliot's M.S. experiment focused on the qualitative analysis of volatile organic compounds (VOCs) transpired by Arroyo willows to document the fate of hydrocarbon contaminants during the

phytoremediation experiments. No volatilization of hydrocarbons occurred in either foliar chambers or soil chambers for the Arroyo willows (Elliot, 2002).

Ken Hoffman adjusted Scott's design to meet the needs of his experiment for his Master's thesis. Since no air samples were necessary for Hoffman's experiment, he used one chamber and did not use spinner flasks. Hoffman conducted multiple experiments to determine the phytostimulation effects of Arroyo willows on diluent contaminated groundwater from Guadalupe. Diluent contaminated groundwater was recirculated through the root zone of the Arroyo willows and the biodegradation rates were measured and compared to soil-only chambers and azide-inhibited controls. Willow trees slightly enhanced the final hydrocarbon biodegradation under the conditions of the laboratory experiments (Hoffman, 2003). The current lupine experiment was based on the willow phytostimulation experiment to enable a direct comparison between the two experiments. Dune lupine (L. chamissonis) was evaluated for the remediation of diluentcontaminated groundwater and compared with the willow experiment. The lupines were expected to increase microbial degradation of the diluent and potentially increase the degradation more than did the willows due to the potential for nitrogen fixation in the lupine roots. 


\section{Lupines}

Of the species of legumes examined thus far, $88 \%$ have the ability to fix nitrogen (Graham and Vance, 2003). The symbiotic relationship between legumes and nitrogen-fixing bacteria is exacting because specific bacteria colonize specific plants. The legumes (peas, beans, soybeans, chickpeas, lupines, and alfalfa) are the principle nitrogen-fixing systems most useful in world agriculture. Lupines (of the family Fabaceae and subfamily Papilionoidae) are a genus of herbaceous annuals and herbaceous to shrubby perennials (Gladstones et al., 1998). Although various varieties of lupines are toxic, lupines are useful legumes for agriculture, biotechnology, and ecology because they have the flexibility to adapt to environmental challenges, their seeds are high in protein and oil content, and they produce various alkaloids (Legocki et al., 1996). Lupines are found all over the world from sub-arctic Alaska to the highlands of east Africa to the sub-tropical lowlands of the southeastern USA (Gladstones et al., 1998). They thrive on soils of low fertility (Gladstones et al., 1998). Lupines typically grow in coarse-textured, well-drained, fairly deep, acid to neutral soils low in nitrogen.

The Lupinus genus is nodulated by the slow-growing soil microorganism Bradyrhizobium (Postgate, 1998; Gladstones et al., 1998) and this symbiosis is exceedingly robust (Gladstones et al., 1998). Lupines do not form mycorrhizal (fungal) associations, as do most agricultural plants (Gladstones et al., 1998). Lupines are not hindered in growth due of this lack of association, because they have other advantages (deep-penetrating, sparse root systems enabling them to scavenge deeply and widely in the soils of low water and nutrient-holding capacity where they grow, and a higher proportion of their root length below the top $20 \mathrm{~cm}$ of soil). This higher proportion of deep root length allows lupines increased access to nutrients and water compared to other legumes (Gladstones et al., 1998).

The lupines were grown from seed harvested at Guadalupe in sand from Guadalupe. Once the lupines were large enough, each lupine was transferred into an individual growth chamber. The chambers consisted of Guadalupe sand, with tubing inserted into the bottom for inflow, and a well for outflow. Diluent-contaminated groundwater was recirculated through the chambers for the 105-day experiment. Degradation was measured through monitoring the total petroleum hydrocarbon (TPH) concentration initially, after 24 days, and after 105 days. Chemical oxygen demand (COD) was measured on 14 occasions as an indicator of the TPH concentration to provide more data to assess the hydrocarbon degradation kinetics. Two sets of control chambers (azide inhibited and soil only) were established alongside the lupine chambers to determine the quantity of biodegradation due to the presence of the lupines.

Diluent-contaminated groundwater was passed through the root system of Dune lupine (Lupinus chamissonis) to ascertain the effects of the rhizosphere on the microbial community and the rate of hydrocarbon biodegradation. The goal of this research was to evaluate whether or not legumes such as Dune lupine stimulate hydrocarbon biodegradation more than non-legumes because of their facilitation of nitrogen fixation. The experiment was conducted in a controlled environment where various variables were eliminated and comparable controls were established. The effects of the rhizosphere were analyzed through monitoring the TPH concentration and COD levels in the groundwater over the length of the experiment. The experimental apparatus 
and materials and methods used were based on the Arroyo willow experiment (Hoffman, 2003). Further details regarding the lupine experiment are available (Martin, 2003).

\section{MATERIALS AND METHODS}

\section{Growth Chambers}

Three sets of three chambers were set up in the laboratory: the first set of chambers with clean soil only, the second set of chambers with clean soil and one lupine per chamber, and the third set with sodium azide at 100 parts per million $(\mathrm{ppm})$ to inhibit microbial activity. Each chamber consisted of a 1-gallon glass jar filled with clean soil from near the phytoremediation field site at Guadalupe and a 2-L reservoir filled with contaminated groundwater from a monitoring well upgradient of the field site (Figure 1). Aluminum foil was placed around the outside of the chambers and reservoirs to prevent algal growth and limit sun U.V. exposure (Figure 2).

\section{Figure 1 - Experimental System}

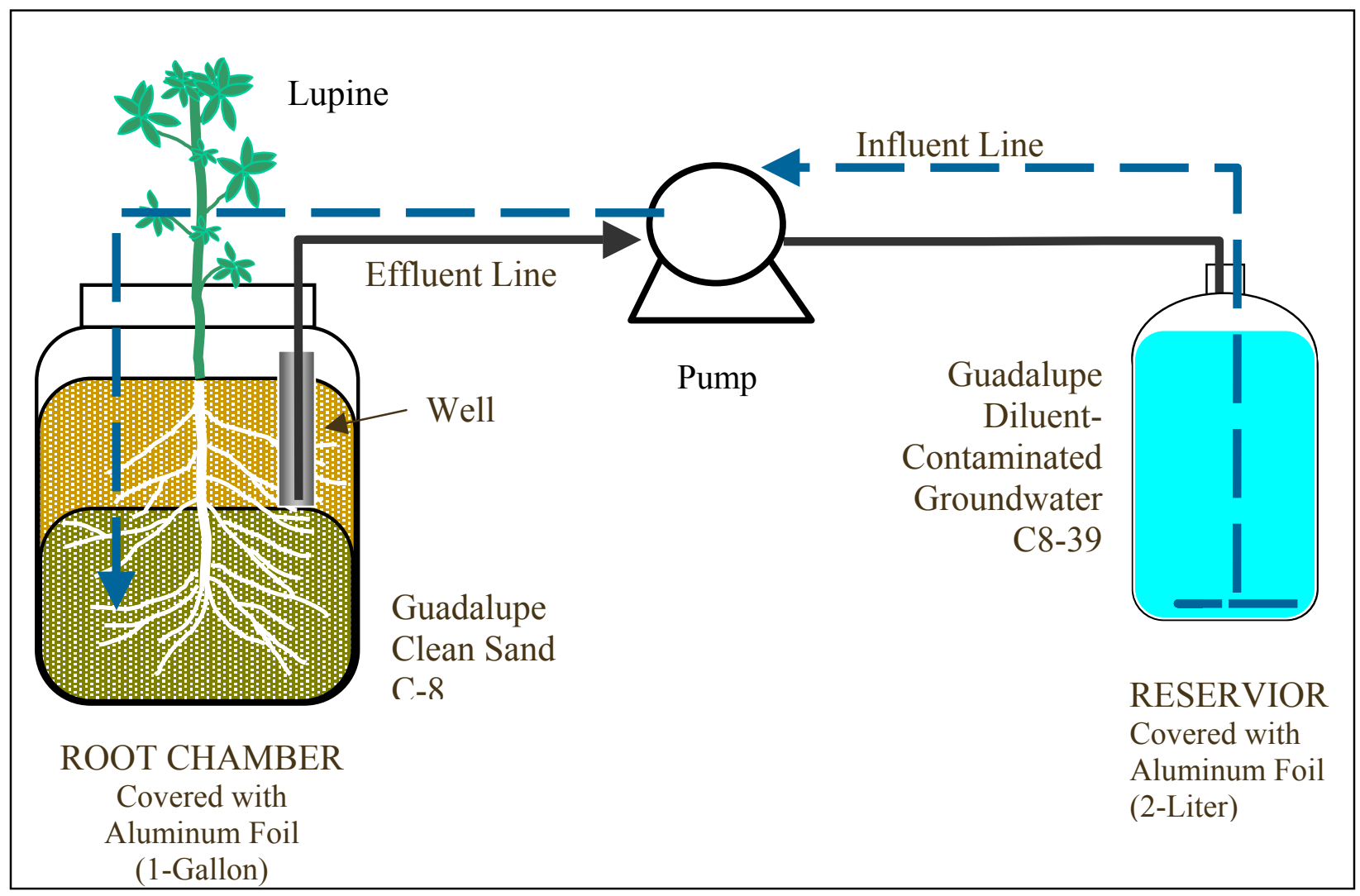

The materials incorporated into the experimental apparatus were carefully chosen to achieve a chemically inert design. By pumping water from the screened well, the groundwater level in the soil could be maintained at a constant height. The wells were placed 1 inch from the top of the chambers. The end of the well in the sand had stainless steel mesh zip-tied to the end of it for screening. The mesh screened out all sands larger than the very fine sands $(0.0020-0.0049$ 
inch), allowing only very small particles (coarse silt, medium silt, fine silt, clay) and water to be pumped into the reservoir.

\section{Figure 2 - Experimental Apparatus}

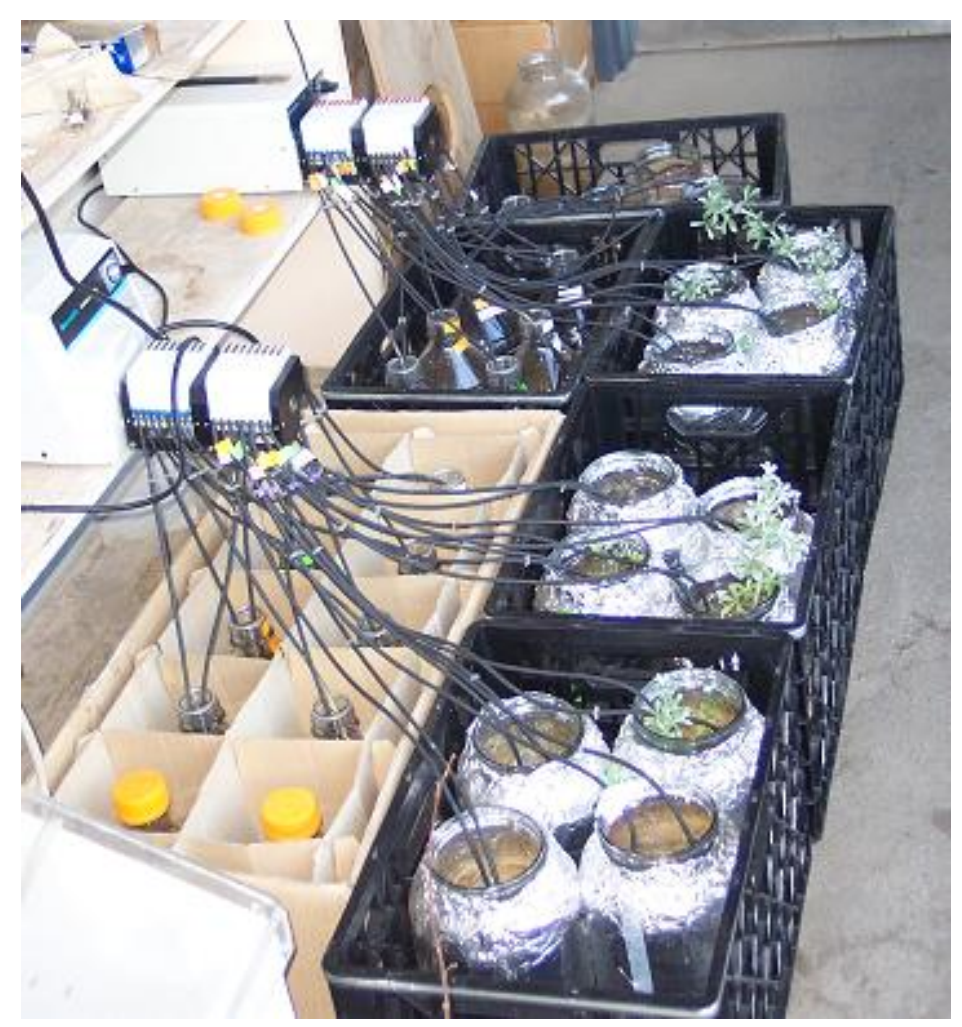

Lupine seeds were obtained from the Unocal Guadalupe site in December 2002. The seeds were scarified to break their outer coat to speed germination. The seeds were planted in two seed trays in clean sand from Guadalupe site C8. The trays were kept indoors while the seeds were germinating. Once the seeds began to grow above the surface, the trays were placed under growth lamps. After 6 weeks, small two-leaved plants were growing and the trays were moved outdoors to harden the plants. After a few weeks of hardening, nine of the plants were transplanted into chambers. Additional plants were maintained in plastic pots to be observed. Control chambers with no plants were filled with sand at the same time the lupines were planted to ensure all other conditions were identical. The lupine seedlings were started in the same $\mathrm{C} 8$ soil as was used throughout the experiment to ensure no additional nutrients or inoculum were introduced by extraneous soil.

For the sodium azide chambers, the sand from $\mathrm{C} 8$ was autoclaved on two separate days. The goal of the azide chambers was to determine how much TPH disappearance was occurring due to non-biological interactions (such as adsorbing to sand particles and tubing). The sand was autoclaved in attempts to kill living organisms in the soil. The sand was autoclaved the second time in an attempt to kill any bacteria having formed from endospores that may have been present in the sand and viable after the initial autoclaving. 
Diluent-contaminated water was obtained from monitoring well C8-39 in April 2003. This well is up-gradient from phytoremediation field site 8 at Guadalupe. Approximately 30 liters of diluent-contaminated groundwater was used to flush the chambers. The goal was to displace the de-ionized water pumped through the chambers with diluent-contaminated groundwater. This was accomplished by pumping the contaminated water from 2-L glass bottles to the chambers. The water was pumped from the chambers into reservoirs and not recirculated. After two days, measurements were taken on the quantity of water pumped through the chambers. Each chamber was pumped until 2 liters of water was displaced.

To begin the recirculation, a 15-gallon plastic container was used to thoroughly mix the diluentcontaminated groundwater. The pumps were stopped and the water was removed from the reservoirs. The reservoirs were filled from the 15-gallon plastic container using a plastic hand pump. After every few reservoirs were filled, the container was shaken again to ensure its contents were not settling and were still well mixed. For chambers 13 through 15, six liters were pumped from the container into a large glass Erlenmeyer flask to which $0.6 \mathrm{~g}$ of sodium azide was added. The six liters were mixed well and used to fill the reservoirs for chambers 13 through 15. Once all the reservoirs were filled, the pumps were started and the water began recirculating.

\section{Water Circulation System}

Peristaltic pumps were used for water recirculation because they were better suited than were centrifugal pumps. While centrifugal pumps are the most common type of pumps, the circulating water would come into direct contact with the pumps internal parts (not considered desirable due to the possibility of contamination of the water by grease or oils associated with the pump). The peristaltic pumps were desirable because they apply pressure to tubing in an undulating motion and continue to pump regardless of the tubing contents. This is important because the inflow was pumping slower than the outflow to avoid flooding the chambers, but this resulted in times when no water was being pumped through the outflow tubing.

Two Masterflex ${ }^{\circledR}$ peristaltic pumps with 10-turn speed controls were used. The pumps had two Ismatec $^{\mathrm{TM}}$ mini-cartridge pump heads with 8 rollers and two 8 -cartridge pump heads attached to each pump. The water circulation system for this experiment was designed to provide a steady flow of water to the chambers thus avoiding the problem of tubing clogs due to sand. For pumping into the chambers the Viton ${ }^{\circledR}$ tubing was $1.65 \mathrm{~mm}$ inner diameter and out of the chambers was $2.79 \mathrm{~mm}$ inner diameter. The tubing for the water return from the chamber to the reservoir was larger to ensure the chambers did not flood. The tubing connecting to the peristaltic pump tubing was all $1 / 8$ inch inner diameter. To connect the peristaltic tubing to the rest of the tubing, clear polypropylene barbed fitting connectors were used.

To pump water from a reservoir into a soil chamber, tubing ran from the bottom of the reservoir to the peristaltic pump tubing, to additional tubing connected to 30 inch long piece of tubing running into the soil chamber. The tubing in the soil chamber had a knot tied at one end, 8 holes ( 0.125 inch) cut into it, and was circled around the bottom of the chamber. The holes were designed to distribute the water flow around the bottom of the chamber. The water was pumped out of the chamber and returned into the reservoir using the well. The tubing was placed into the 
bottom of the well, thereby determining the water level in the chamber. One pump head was used for pumping water from the reservoirs into the chambers and one pump head per peristaltic pump was used to pump the water out of the wells into the reservoirs. The pumps were set to rotate at the same number of revolutions per minute. Water lost due to evaporation and evapotranspiration was replaced with de-ionized water at least weekly. Beginning on day 28 , the volume of water replaced was monitored to the nearest $5 \mathrm{~mL}$.

\section{Analytical Methods}

Several analytical methods were employed to examine the biodegradation of the diluent and to ensure the experiment was operating as designed. These included TPH analysis, nutrient analysis, COD analysis, plant growth measurements, evaporation monitoring, and soil microorganism analysis.

\section{Total Petroleum Hydrocarbon Analysis}

TPH sampling was conducted on days 0,24 , and 105 . One-liter amber sample bottles were used for sampling. During sampling, the pumps were turned off. The reservoir to be sampled was capped, inverted many times, and shaken vigorously insuring it would be well mixed. Then, the one-liter sample bottle was filled until the top had a rounded layer of water above the top to reduce the quantity of air in the sample bottle. The sample bottle was then placed on ice. On day 0 , the three sets of three chambers were sampled. On day 24, the same chambers were sampled. On day 74, three different plant chambers were sampled to determine the TPH concentration. The 2-L reservoirs only allow for two TPH samples. At day 105, the 12 previously sampled (day 24) chambers were sampled again. On each sampling day, immediately upon sampling completion, the samples were taken to ZymaX Envirotechnology, Inc. (San Luis Obispo, CA) for analysis using gas chromatography/mass spectrophotometry (GC/MS). ZymaX uses EPA method 3510 for extraction. ZymaX uses a State of California method for TPH analysis similar to EPA method 8015. The TPH carbon chain distributions were determined using a simulated distillation (SIM-DIS) protocol. The analytical range was $\mathrm{C}_{8}-\mathrm{C}_{40}$ and the TPH was quantified against diluent.

\section{Nutrient Sampling}

Samples were taken for nitrate $\left(\mathrm{NO}_{3}-\mathrm{N}\right)$, nitrite $\left(\mathrm{NO}_{2}-\mathrm{N}\right)$, orthophosphate, sulfate, total phosphorus as $\mathrm{P}$, and ammonia $\left(\mathrm{NH}_{3}-\mathrm{N}\right)$ on day 0 and at the conclusion of the experiment. After the samples were drawn, they were placed on ice and transported to ZymaX for analysis. ZymaX analyzed the samples using EPA method 300.0 for $\mathrm{NO}_{3}-\mathrm{N}, \mathrm{NO}_{2}-\mathrm{N}$, orthophosphate, and sulfate, EPA method 365.2 for total phosphorus as P, and EPA method 350.3 for $\mathrm{NH}_{3}-\mathrm{N}$.

\section{Chemical Oxygen Demand (COD)}

Due to the expectation of COD being an indicator of TPH concentration, COD was measured periodically throughout the experiment. COD is commonly used in wastewater treatment as a rapid way to ascertain the level of pollution in wastewater. It is a measure of the quantity of oxygen used in biological and non-biological oxidation of materials in water. COD is the 
equivalent amount of oxygen an oxidizing reagent consumes by a complete oxidation of a substance under laboratory conditions. The benefit of testing COD in addition to TPH is the data can be collected more frequently than can TPH data because only $2.5 \mathrm{~mL}$ is required for the COD analysis compared to $1 \mathrm{~L}$ for the TPH analysis. This allowed for insight into the kinetics of $\mathrm{TPH}$ degradation because of the frequent sampling. The theoretical COD of diluent was calculated to estimate the expected COD readings due to the diluent. Hydrocarbons in the range of $\mathrm{C}_{10}$ to $\mathrm{C}_{32}$ were present in the groundwater used in the willow experiment (Hoffman, 2003), therefore the theoretical oxygen demand values for $\mathrm{C}_{16}, \mathrm{C}_{24}$, and $\mathrm{C}_{32}$ were calculated. The theoretical oxygen demand is essentially the same across the diluent range and the average value $3.45 \mathrm{mg} \mathrm{O}_{2}$ per $\mathrm{mg}$ of diluent was taken as representative of the diluent.

Low (5 - $150 \mathrm{mg} \mathrm{COD/L}$ ) and standard range (20 - $900 \mathrm{mg}$ COD/L) accu-test ${ }^{\circledR}$ twist-cap vials (Bioscience, Inc.) were used for the COD testing. The main ingredients in the COD vials are sulfuric acid $\left(\mathrm{H}_{2} \mathrm{SO}_{4}\right)$ and potassium dichromate $\left(\mathrm{K}_{2} \mathrm{Cr}_{2} \mathrm{O}_{7}\right)$. Silver sulfate $\left(\mathrm{Ag}_{2} \mathrm{SO}_{4}\right)$, mercuric sulfate $\left(\mathrm{HgSO}_{4}\right)$, and sulfamic acid $\left(\mathrm{NH}_{2} \mathrm{SO}_{3} \mathrm{H}\right)$ are contained in the vials to catalyze oxidation and limit chloride interference. As organic material in the sample is oxidized, Cr (VI) in the dichromate (yellow) is reduced to $\mathrm{Cr}$ (III) (green). In the low range vials, the decrease in the concentration of the $\mathrm{Cr}$ (VI) ion is measured to determine the COD. In the standard range vials, the increase in the concentration of the $\mathrm{Cr}$ (III) ion is measured. The twist-cap vial method used is equivalent to EPA Method 410.4.

The COD reactor was turned on before the COD sampling began to allow it to heat to $150^{\circ}$ Celsius. For each sample, the cap was twisted off and $2.5 \mathrm{~mL}$ of sample was carefully pippetted down the side of the vial forming a layer on top of the reagents. The twist cap was replaced and the contents of the vial were thoroughly mixed by shaking. The vials were placed into the COD heater block for 2 hours, removed, shaken, allowed to cool allowing any suspended precipitate to settle for at least 10 minutes. The light absorbance was measured using a Hitatchi 3010 Spectrophotometer. For the low range vials, the spectrophotometer was set to $440 \mathrm{~nm}$, initialized, and zeroed using de-ionized water. Slightly more than $1 \mathrm{~mL}$ of sample was poured from the vial into a new disposable plastic cuvette and placed into the spectrophotometer. All absorbance readings were recorded. For the standard range vials, the spectrophotometer was set to $600 \mathrm{~nm}$ and the same process as for the low range vials was repeated. The low range vials were used for the plant and no plant chambers (1 through 12) and the standard range vials were used for the sodium azide chambers (13 through 15).

COD calibration curves were made for the low and standard range vials using potassium acid phalate (KHP) as a TPH surrogate. A KHP $10 \mathrm{~g} \mathrm{COD/L} \mathrm{stock} \mathrm{solution} \mathrm{was} \mathrm{prepared} \mathrm{by} \mathrm{adding}$ $8.5034 \mathrm{~g}$ of KHP previously dried to a standard weight at $110^{\circ} \mathrm{Celsius}$ to a volumetric flask and diluting it to $1000 \mathrm{~mL}$ using Class I de-ionized water. The stock solution was diluted to cover the expected sample range and the overall range of the vials. Each concentration was run in duplicate. The calibration curves for the COD vials were linear with $\mathrm{R}^{2}$ values of 0.9993 for the low range vials and 0.9995 for the standard range vials. The theoretical chemical oxygen demand for $\mathrm{KHP}$ or $\mathrm{KOCOC}_{6} \mathrm{H}_{4} \mathrm{COOH}\left(\mathrm{KH}_{5} \mathrm{C}_{8} \mathrm{O}_{4}\right)$ is $1.175 \mathrm{mg} \mathrm{O}_{2}$ per mg KHP. 


\section{Plant Growth and Evapotranspiration Rates}

The growth of the lupines was monitored throughout the experiment. Periodically, leaves were counted for each plant. The leaves were classified as small, medium or large and were counted in leaf sets. The leaves typically grew in six at a time. A visit to Guadalupe was conducted to view lupines on the site. At the end of the experiment, destructive sampling of plants was conducted to determine if nodules were present. Water loss from the reservoirs due to evaporation loss was measured to determine evapotraspiration by the lupines.

\section{Terminal Restriction Fragment (TRF) Analysis}

At the end of the lupine experiments, the microbial community in the soil from each chamber was examined using TRF analysis to see if community structure differed in the chambers with plants compared to chambers with soil only. At the end of the experiment, soil samples were collected to analyze the microbial communities present in the soil due to pumping contaminated groundwater through the soil. Soil samples were taken from the soil only $(1,5$, and 9$)$, plant $(6$, 7 , and 11), and sodium azide $(13,14$, and 15) chambers. Core samples were taken using a graduated cylinder. The analysis of the soil samples was conducted by EBI researchers at Cal Poly.

\section{RESULTS AND DISCUSSION}

\section{Hydrocarbon Biodegradation Rates}

The aqueous TPH concentrations of the duplicate initial samples were 5.4 and $5.5 \mathrm{mg}$ TPH per liter of contaminated groundwater (Table 1). After 24 days, the triplicate soil only and plant chambers had TPH concentrations of $1.6 \pm 0.12$ and $1.5 \pm 0.06 \mathrm{mg} / \mathrm{L}$, respectively (Table 1 and Figure 3). This indicates TPH removal of $72.3 \%$ and $72.9 \%$ for the soil only and plant chambers, respectively, indicating the lupines did not enhance biodegradation during this short time frame. A significant difference existed between the sodium azide control and the lupine and soil only chambers (Figure 3 ) evidenced by p-values less than 0.05 using 2 -sample t-tests. The sodium azide chambers had a substantial TPH disappearance of $58 \%$ after 24 days with a TPH concentration of $2.3 \pm 0.23 \mathrm{mg} / \mathrm{L}$. However, significantly less reduction in TPH was observed for the sodium azide control than did for the soil only and lupine chambers. The $58.4 \%$ reduction in TPH for the sodium azide control may have been due to TPH adsorption to soil or to partial TPH biodegradation, since sodium azide does not completely stop microbial activity (Palmroth et al., 2002). Also, the low sodium azide concentration used for these controls (100 ppm) may have been insufficient to inhibit all microbial activity. A similar study using 1000 ppm sodium azide showed greatly reduced TPH loss (Hoffman, 2003).

After 105 days, the TPH concentrations decreased to $0.67 \pm 0.085$ and $0.33 \pm 0.12 \mathrm{mg} / \mathrm{L}$, respectively for the soil only and lupine chambers (Table 1). This indicates a TPH removal of $87.8 \%$ for the soil only and $93.9 \%$ for the lupine chambers. Statistically, a significant difference existed between these two sets of chambers ( $p=0.031$ for two sample $t$-test with $95 \%$ confidence interval) indicating the lupines significantly enhanced biodegradation over the 105day experiment. The sodium azide chambers also exhibited a substantial TPH reduction of 82.6 
$\%$ after 105 days with a final TPH concentration of $0.95 \pm 0.218 \mathrm{mg} / \mathrm{L}$. Based on 2 sample ttests, no significant difference existed between the sodium azide and soil only chambers $(\mathrm{p}=$ $0.17)$ and between the sodium azide and the lupine chambers $(\mathrm{p}=0.024)$. Although HC adsorption to roots was not examined, it was not expected to be significant due to the minimal root structure of the lupines. The sodium azide concentration may have decreased throughout the experiment resulting in the sodium azide control becoming more similar to the soil only control.

Table 1 - TPH Concentrations During Biodegradation with and without Lupines and for Sodium Azide Inhibited Controls

\begin{tabular}{|c|c|c|c|c|c|c|c|c|c|}
\hline Day & $\begin{array}{r}\text { Chambe } \\
\text { r Type }\end{array}$ & $\begin{array}{l}\text { Chamber } \\
\text { Number }\end{array}$ & \begin{tabular}{|r|}
$\mathrm{TPH}$ \\
Conc. \\
$*$ \\
$\mathrm{mg} / \mathrm{L}$ \\
\end{tabular} & HC Range & $\begin{array}{r}\text { Ave } \\
\text { TPH } \\
\mathrm{mg} / \mathrm{L}\end{array}$ & $\begin{array}{r}\text { Std } \\
\text { Dev }\end{array}$ & $\begin{array}{r}\% \text { Initial } \\
\mathrm{TPH}\end{array}$ & $\begin{array}{r}\text { Avg } \% \\
\text { Initial } \\
\text { TPH }\end{array}$ & $\begin{array}{r}\text { Std } \\
\text { Dev }\end{array}$ \\
\hline 0 & \multirow{2}{*}{ Initial } & $\mathrm{N} / \mathrm{A}$ & 5.40 & C10-C32 & \multirow{2}{*}{5.45} & \multirow{2}{*}{0.071} & 99.1 & \multirow{2}{*}{100.0} & \multirow{2}{*}{1.3} \\
\hline 0 & & $\mathrm{~N} / \mathrm{A}$ & 5.50 & $\mathrm{C} 10-\mathrm{C} 32$ & & & 100.9 & & \\
\hline 24 & \multirow{3}{*}{$\begin{array}{l}\text { Soil } \\
\text { only }\end{array}$} & 1 & 1.70 & C12-C30 & \multirow{3}{*}{1.57} & \multirow{3}{*}{0.115} & 31.2 & \multirow{3}{*}{28.7} & \multirow{3}{*}{2.5} \\
\hline 24 & & 5 & 1.50 & C11-C32 & & & 27.5 & & \\
\hline 24 & & 9 & 1.50 & C12-C26 & & & 27.5 & & \\
\hline 24 & \multirow{3}{*}{$\begin{array}{r}\text { Lupine } \\
\text { and Soil }\end{array}$} & 6 & 1.50 & C12-C30 & \multirow{3}{*}{1.53} & \multirow{3}{*}{0.058} & 27.5 & \multirow{3}{*}{28.1} & \multirow{3}{*}{1.4} \\
\hline 24 & & 7 & 1.60 & C11-C32 & & & 29.4 & & \\
\hline 24 & & 11 & 1.50 & $\mathrm{C} 12-\mathrm{C} 26$ & & & 27.5 & & \\
\hline 24 & \multirow{3}{*}{$\begin{array}{r}\text { Azide } \\
\text { Inhibite } \\
\mathrm{d}\end{array}$} & 13 & 2.40 & C10-C32 & \multirow{3}{*}{2.27} & \multirow{3}{*}{0.231} & 44.0 & \multirow{3}{*}{41.6} & \multirow{3}{*}{4.8} \\
\hline 24 & & 14 & 2.00 & C10-C32 & & & 36.7 & & \\
\hline 24 & & 15 & 2.40 & C10-C32 & & & 44.0 & & \\
\hline 74 & \multirow{3}{*}{$\begin{array}{l}\text { Lupine } \\
\text { and Soil }\end{array}$} & 3 & 0.68 & C14-C28 & \multirow{3}{*}{0.697} & \multirow{3}{*}{0.029} & 12.5 & \multirow{3}{*}{12.8} & \\
\hline 74 & & 10 & 0.73 & C14-C28 & & & 13.4 & & 0.7 \\
\hline 74 & & 12 & 0.68 & C14-C28 & & & 12.5 & & \\
\hline 105 & & 1 & 0.75 & C14-C32 & & & 13.8 & & \\
\hline 105 & $\begin{array}{l}\text { Soll } \\
\text { only }\end{array}$ & 5 & 0.58 & C16-C32 & 0.667 & 0.085 & 10.6 & 12.2 & 1.8 \\
\hline 105 & & 9 & 0.67 & C16-C30 & & & 12.3 & & \\
\hline 105 & I Inin & 6 & 0.30 & C16-C30 & & & 5.5 & & \\
\hline 105 & $\begin{array}{l}\text { Lupine } \\
\text { and Soil }\end{array}$ & 7 & 0.23 & C16-C28 & 0.333 & 0.123 & 4.2 & 6.1 & 4.9 \\
\hline 105 & & 11 & 0.47 & C14-C28 & & & 8.6 & & \\
\hline 105 & Azide & 13 & 0.85 & C12-C32 & & & 15.6 & & \\
\hline 105 & Inhibite & 14 & 0.80 & C12-C32 & 0.950 & 0.218 & 14.7 & 17.4 & 3.1 \\
\hline 105 & d & 15 & 1.20 & $\mathrm{C} 12-\mathrm{C} 32$ & & & 22.0 & & \\
\hline
\end{tabular}

In similar experiment (133 days) with willow trees, after 20 days the percentages of initial TPH removed were $80.4 \%$ for the soil only, $77.3 \%$ for the willow, and $53.6 \%$ for the sodium azide 
chambers (Hoffman, 2003 and Hoffman and Nelson, 2003). The time period (20 days) was four days shorter, but the degradation was slightly more rapid for the soil only and vegetated chambers in the willow experiment. However, in this willow experiment the sodium azide chamber degradation was slightly slower $(53.6 \%$ vs. $58.4 \%$ removed) than in the lupine experiment. This could be due to the higher sodium azide concentration used in the willow experiment.

In the 105-day willow experiment (Hoffman, 2003), the soil only, willow, and sodium azide chambers had 89.9, 92.8, and $45.3 \%$ of the initial TPH concentration removed from the groundwater in the respective chambers at the end of the experiment. These results are similar to the results obtained in this experiment (soil only $87.8 \%$ and lupine $93.9 \%$ removed), except for the sodium azide chambers due to the lower sodium azide concentration used in the lupine experiment.

Figure 3 - TPH Concentrations Initially (2 Replicates) and at 24 and 105 Days (3 Replicates Per Set)

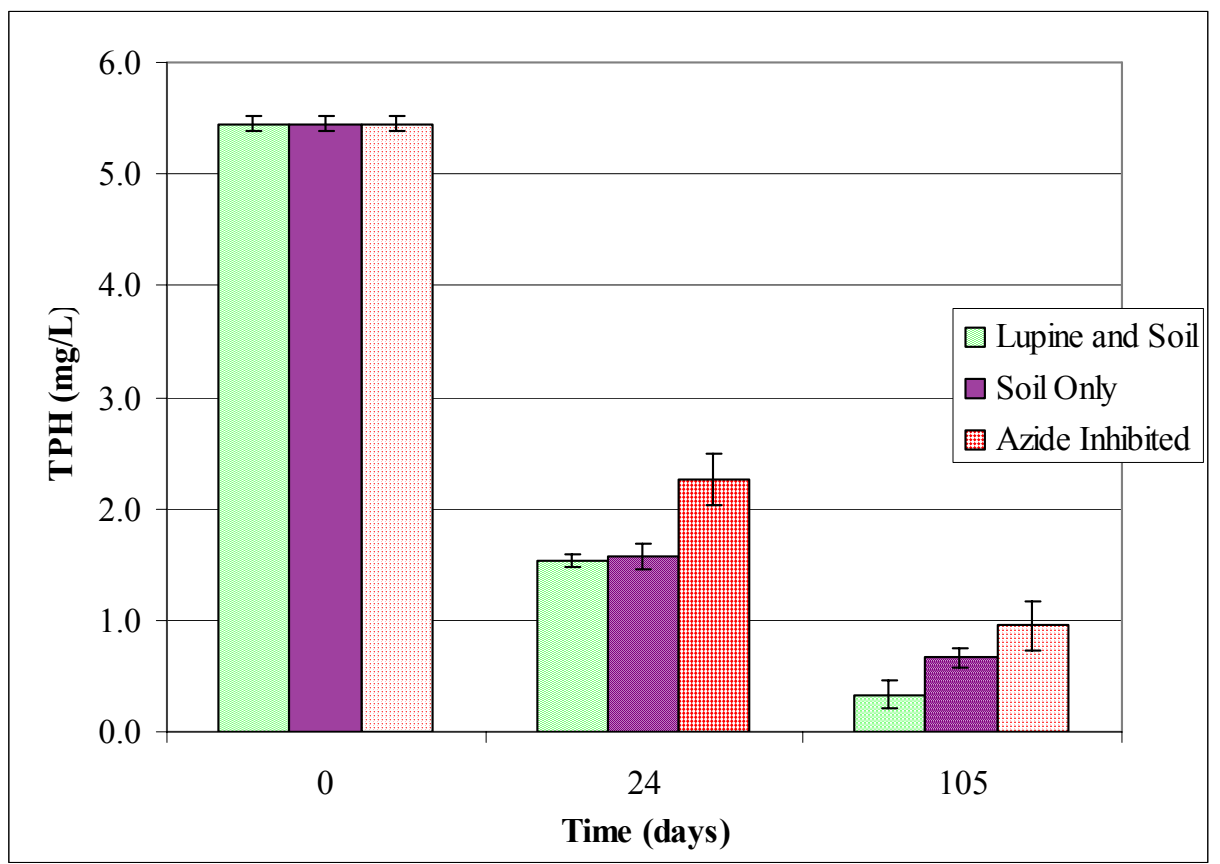

The hydrocarbon composition of the samples was evaluated by integrating the GC/MS chromatograms in segments, thus providing estimates for the TPH concentration for each equivalent carbon range. The equivalent ranges tested were between $\mathrm{C}_{10}$ and $\mathrm{C}_{40}$, however no $\mathrm{C}_{32}-\mathrm{C}_{36}$ or $\mathrm{C}_{36}-\mathrm{C}_{40}$ ranges were detected in the groundwater. Significant TPH degradation occurred across all the carbon ranges after 24 days (Figure 4). Between 24 and 105 days, a less dramatic decrease in TPH was observed for all ranges (Figure 4). The overall carbon range distribution appears to be similar initially, at 24 days, and at 105 days, with the concentrations decreasing over time. At 24 days, the $\mathrm{C}_{10}-\mathrm{C}_{12}$ range was virtually gone in the soil only and plant chambers. By 105 days the $\mathrm{C}_{10}-\mathrm{C}_{12}$ range had been removed from all sets of chambers. At 105 days, the $\mathrm{C}_{12}-\mathrm{C}_{14}$ ranges were removed from the groundwater for the soil only and plant 
chambers and were minimal in the sodium azide chambers. Minimal concentrations of $\mathrm{C}_{14}-\mathrm{C}_{16}$ range $\mathrm{HC}$ were present in the soil only and plant chambers at 105 days. For $\mathrm{C}_{28}-\mathrm{C}_{32}$, only minimal concentrations existed after 24 days, however the average soil only chamber concentration increased from 24 to 105 days. The standard deviations of the average concentrations do not overlap, however the concentration at 24 days is not significantly different than at 105 days $(\mathrm{p}=0.14$ for 2 sample t-test with $95 \%$ confidence interval). Shorter chain hydrocarbons are not expected to combine into longer chains, thus the only explanation for the increase is some error. In the soil only chambers, no TPH removal was observed between days 24 and 105 for the $\mathrm{C}_{24}-\mathrm{C}_{28}$ range.

Figure 4 - Effect of Biodegradation on TPH Equivalent Carbon Chain Range Distribution

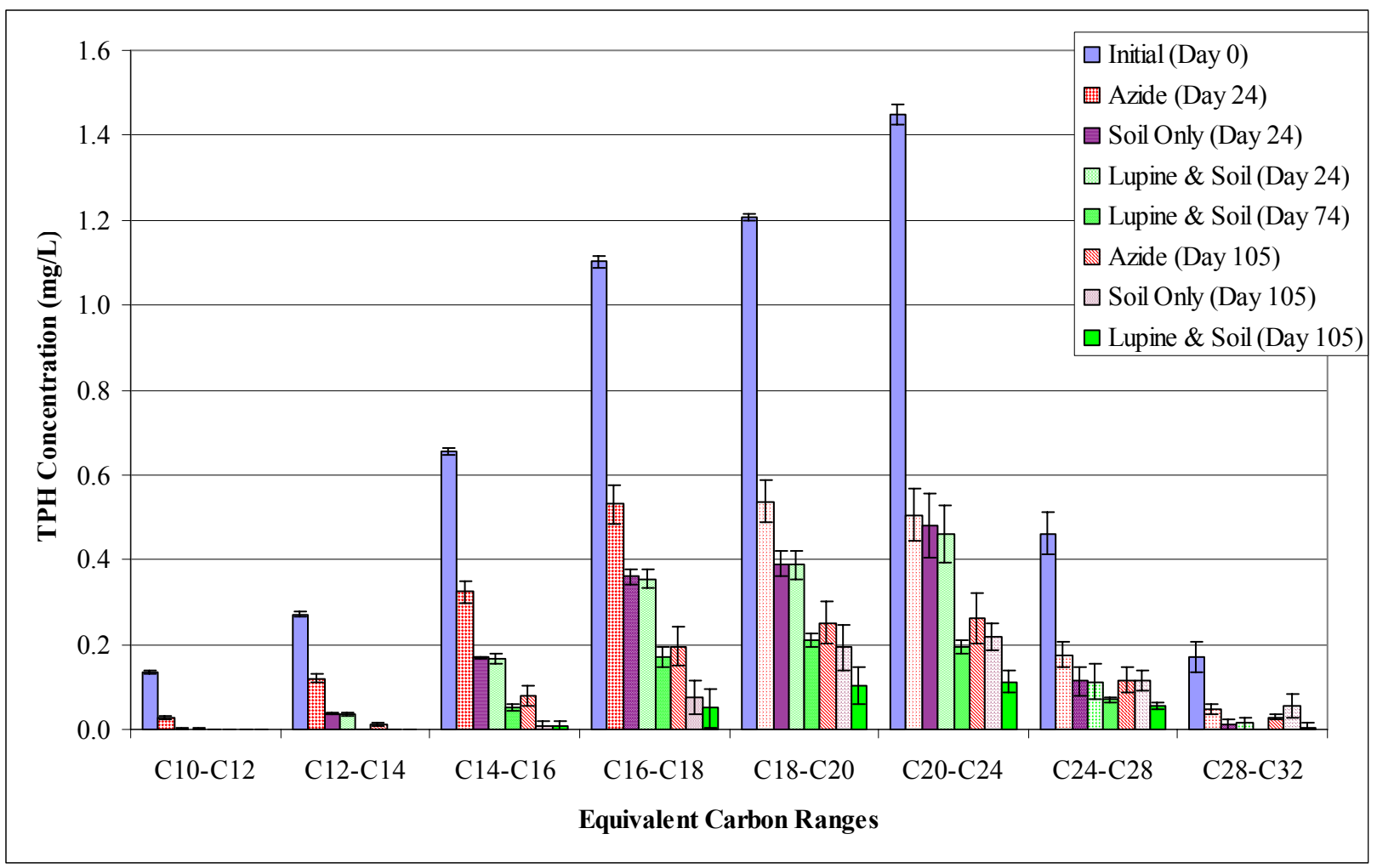

To further describe how the composition of the TPH in the groundwater changed over time, the percent of the total TPH for each TPH fraction for each sampling day was calculated. For example, after 105 days in the soil only chambers for the carbon range of $\mathrm{C}_{18}-\mathrm{C}_{20}$ the average TPH concentration was $0.193 \mathrm{mg} / \mathrm{L}$ and the overall TPH concentration was $0.667 \mathrm{mg} / \mathrm{L}$ for $29 \%$ total TPH. The trends in composition change observed for the lupine (Figure 5) and soil only (Figure 6) chambers are very similar and indicate how the longer chain $\mathrm{HC}$ constitute more of the TPH as time progressed and the shorter chain $\mathrm{HC}$ were removed. These figures reveal the rapid degradation of $\mathrm{C}_{16}-\mathrm{C}_{18}$ and the minimal degradation of $\mathrm{C}_{24}-\mathrm{C}_{28}$ fraction during the 24 to 105 day period. In the plant chambers the $\mathrm{C}_{16}-\mathrm{C}_{18}$ range $\mathrm{HC}$ went from constituting $23 \%$ of the total at day 24 to $13 \%$ at day 105 . This increased degradation may be due to the easier to degrade ranges having already been removed and $\mathrm{C}_{16}-\mathrm{C}_{20}$ may have been the next easier range for degradation. In the plant chambers, $7 \%$ of the $\mathrm{C}_{24}-\mathrm{C}_{28}$ range remained at 24 days and $18 \%$ 
at 105 days. This range appears to be more difficult to degrade. The TPH in the sodium azide chambers (Figure 7) appear to have degraded slower and compositions at day 105 are similar to compositions in the plant and soil only chambers after 24 days. No significant reduction of $\mathrm{C}_{16}$ $\mathrm{C}_{18}$ occurred in the sodium azide chambers, but a slight increase in the percent of $\mathrm{C}_{24}-\mathrm{C}_{28}$ at 105 days was observed.

The results were analyzed by examining the percentage of the initial TPH remaining for each carbon range. This enabled the data to be characterized relative to the carbon ranges that had degraded the most (Figure 8). The overall TPH removal during the first 24 days was very rapid, while the removal was much slower between 24 and 105 days. At 24 days, for the soil only and plant chambers less than $40 \%$ of the initial TPH remained across all the carbon ranges. For the plant chambers measured on day 74 , less than $20 \%$ of the initial TPH remained for all carbon ranges. At day 24, on average the sodium azide chambers had less than $50 \%$ of the initial TPH remaining for all carbon ranges. After 105 days in the plant chambers, $12 \%$ or less of the initial TPH remained for all the ranges, while in the soil only chambers the TPH remaining was as high as $33 \%$. The sodium azide chambers had $25 \%$ or less TPH remaining at 105 days. The highest percentages of the initial TPH remaining for the sodium azide and plant chambers was in the range $\mathrm{C}_{24}-\mathrm{C}_{28}$ at day 105 .

After 24 days, in the soil only chambers between 26 and $33 \%$ of the initial TPH remained for $\mathrm{C}_{14}-\mathrm{C}_{28}$ carbon chain ranges. The remaining three ranges $\left(\mathrm{C}_{10}-\mathrm{C}_{12}, \mathrm{C}_{12}-\mathrm{C}_{14}\right.$, and $\left.\mathrm{C}_{28}-\mathrm{C}_{32}\right)$ had between 1 and $14 \%$ of the initial TPH remaining. The results for the plant chambers at 24 days were similar. For the sodium azide chambers, at 24 days, between 35 and $50 \%$ of the initial TPH remained for $\mathrm{C}_{12}-\mathrm{C}_{28}$ carbon chain ranges. The $\mathrm{C}_{10}-\mathrm{C}_{12}$ range had $20 \%$ remaining and the $\mathrm{C}_{28}-\mathrm{C}_{32}$ range had $28 \%$ of the initial TPH remaining.

After 105 days, in the soil only chambers between 16 and $25 \%$ of the initial TPH remained for $\mathrm{C}_{18}-\mathrm{C}_{28}$ carbon chain ranges. The $\mathrm{C}_{28}-\mathrm{C}_{32}$ range had an erroneous increase in TPH concentration. The remaining four ranges $\left(\mathrm{C}_{10}-\mathrm{C}_{18}\right)$ had between 0 and $7 \%$ of the initial TPH remaining. The plant chambers had $12 \%$ remaining in the $\mathrm{C}_{24}-\mathrm{C}_{28}$ range, while the remaining ranges $\left(\mathrm{C}_{10}-\mathrm{C}_{24}\right.$ and $\left.\mathrm{C}_{28}-\mathrm{C}_{32}\right)$ had between 0 and $8.5 \%$ of the initial TPH remaining. For the sodium azide chambers, at 105 days, zero and $4.9 \%$ of the initial TPH remained for the $\mathrm{C}_{10}-\mathrm{C}_{14}$ carbon chain ranges, while between 12 and $25 \%$ of the initial TPH remained in the other carbon ranges. After 105 days, a higher percentage of some of the heavier hydrocarbons remained in the groundwater indicating those particular long-chain hydrocarbons were less biodegradable.

After 105 days, the primary willow experiment (Hoffman, 2003) found less than $20 \%$ of the initial TPH remaining for the soil only, $11 \%$ for the willow, and $71 \%$ for the sodium azide chambers. In the repeat of the primary willow experiment, after 133 days less than $20 \%$ of the initial TPH remained for the soil only chambers, $10 \%$ for the willow, and $50 \%$ for the sodium azide chambers (Hoffman, 2003). In the lupine experiment, over $50 \%$ of the TPH in the sodium azide chambers had been removed at 24 days. This discrepancy is probably due to the concentration of sodium azide used. The sodium azide concentration used for this experiment was $100 \mathrm{ppm}$ or $0.1 \%$, while in Hoffman's experiment it was $1 \%$. However, significant quantities of sodium azide (such as 0.5 and $1 \%$ ) change the structure of the soil (Palmroth et al., 2002; Wang and Jones, 1994). 
Figure 5 - Normalized TPH Equivalent Carbon Chain Range Distribution by \% of Total TPH by Day for the Lupine Chambers

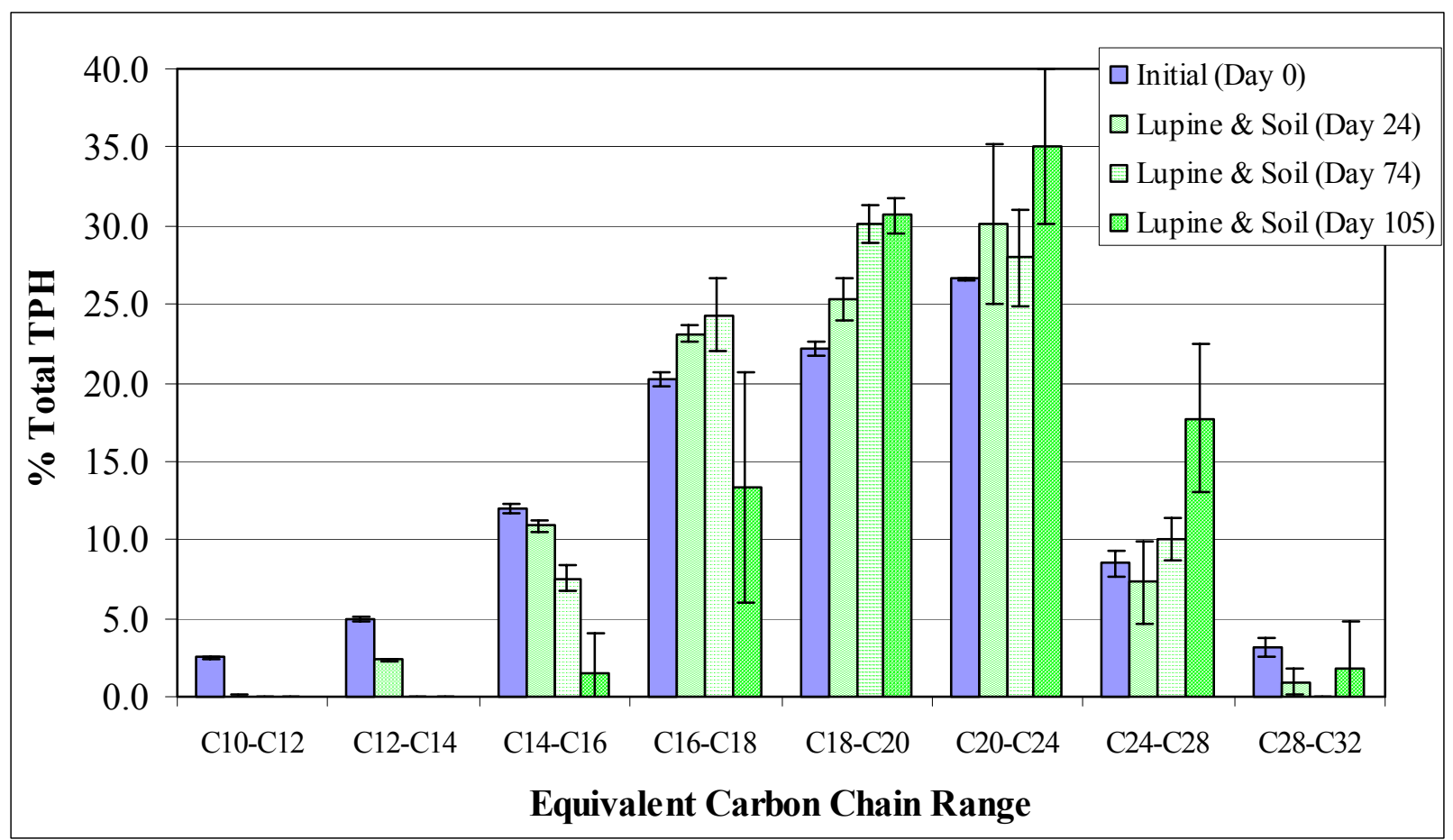

Figure 6 - Normalized TPH Equivalent Carbon Chain Range Distribution by \% of Total TPH by Day for the Soil Only Chambers

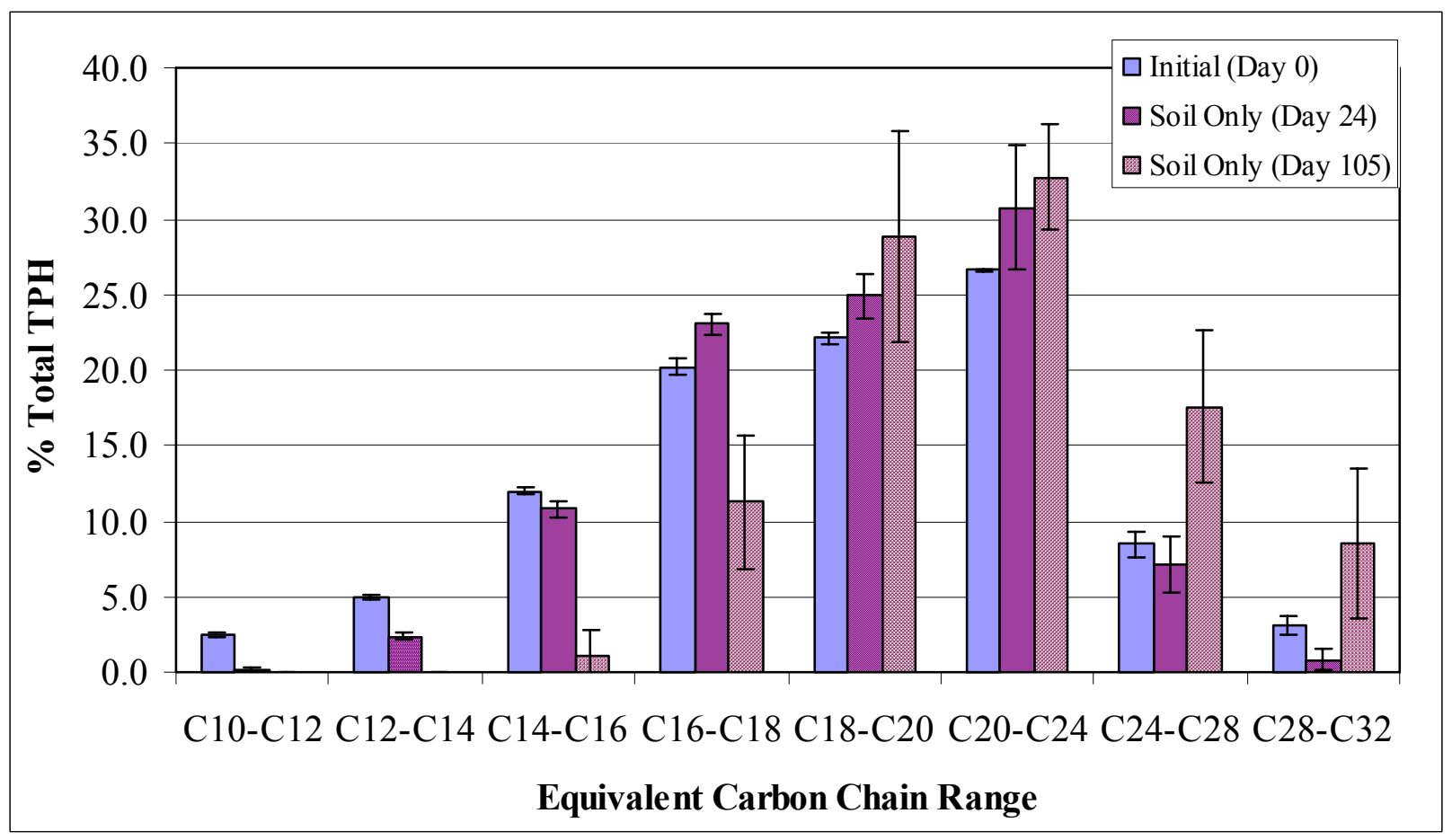


Figure 7 - Normalized TPH Equivalent Carbon Chain Range Distribution by \% of Total TPH by Day for the Sodium Azide Chambers

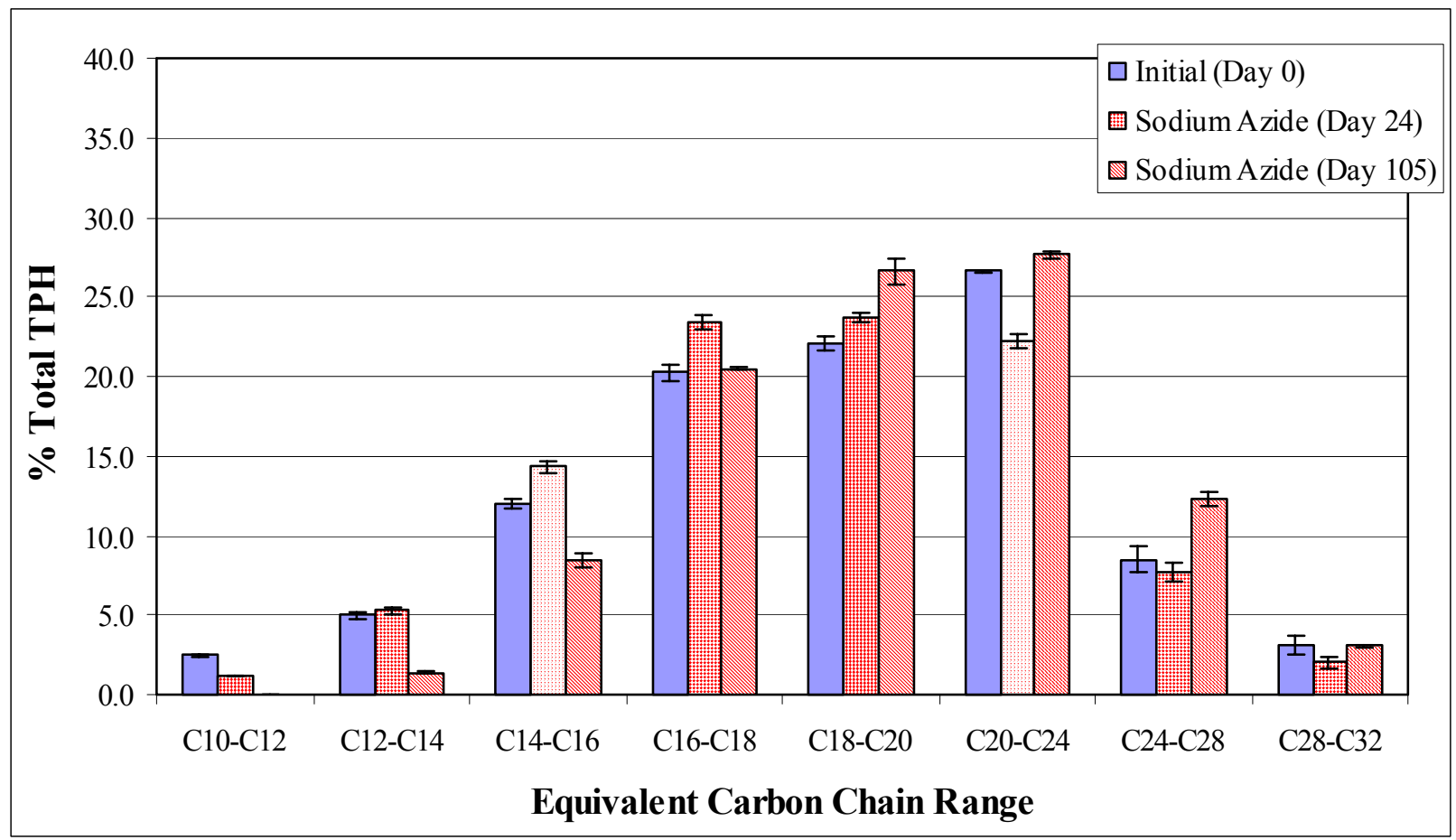

Figure 8 Normalized TPH Equivalent Carbon Chain Range Distribution by \% of Initial TPH Remaining

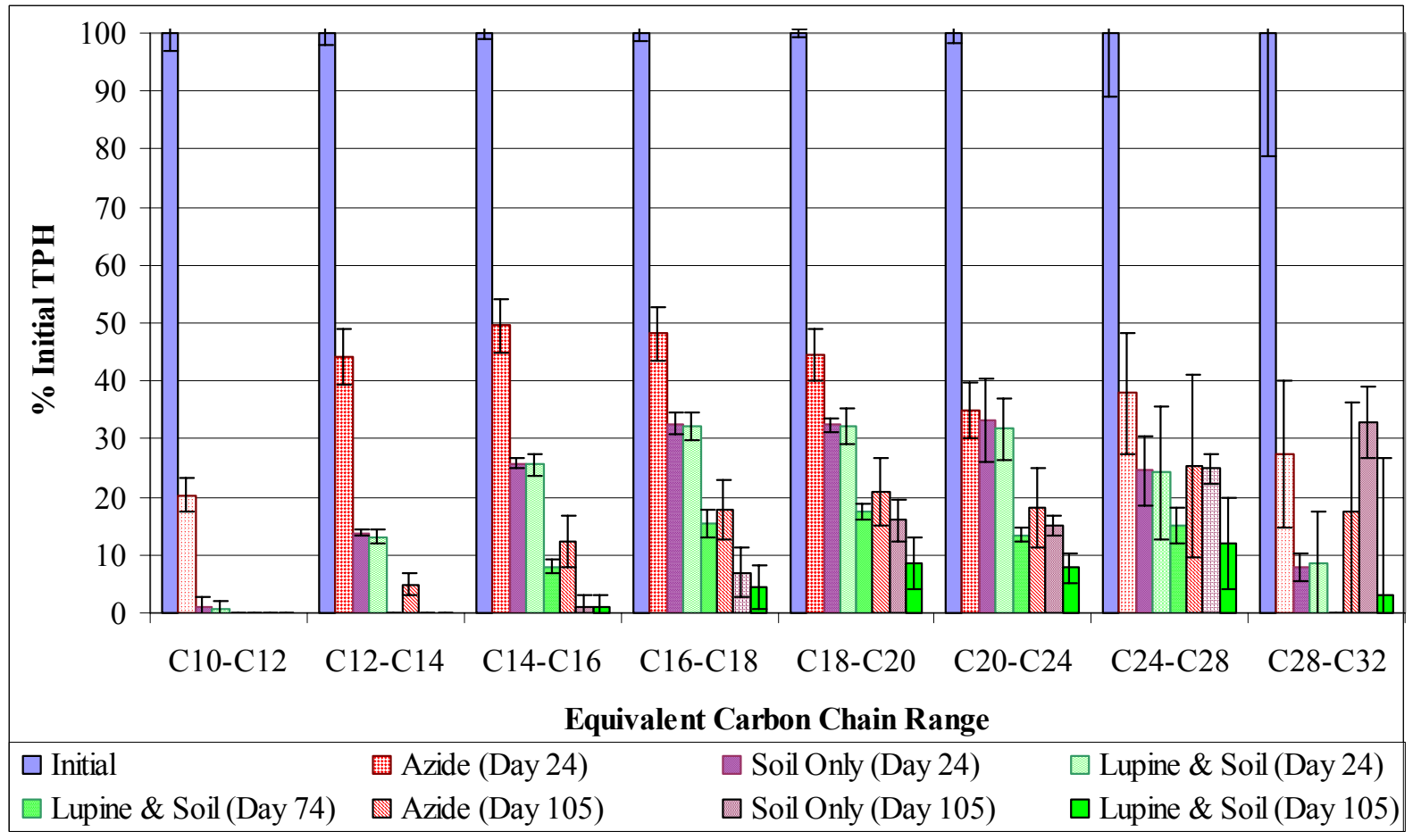




\section{Effect of Biodegradation on COD Concentrations as a Surrogate for TPH}

COD was measured at days $0,2,3,5,8,18,24,30,39,54,61,74,84$ and 105 as a surrogate for hydrocarbon concentration. The initial average COD values for groundwater from the soil only chambers was $99.8 \mathrm{mg} \mathrm{COD} / \mathrm{L}$, for the lupine chambers it was 99.5 , and for the sodium azide chambers it was $183 \mathrm{mg} \mathrm{COD} / \mathrm{L}$ (Table 2 ). The addition of sodium azide significantly increased the COD of the water. Sodium azide is a strong reducing agent. In the COD vials the sodium azide was chemically oxidized consuming large quantities of oxygen and increasing the COD of the groundwater. Based on the theoretical COD of diluent being $3.45 \mathrm{mg} \mathrm{O}_{2}$ per $\mathrm{mg}$ diluent, and the initial TPH concentrations being an average of $5.45 \mathrm{mg} / \mathrm{L}$, the initial COD values were expected to be approximately $18.8 \mathrm{mg} \mathrm{COD} / \mathrm{L}$. Other components of the groundwater appear to exert a COD in addition to the COD due to the diluent contamination.

As expected, the COD of the contaminated water in the soil only and plant chambers were basically the same initially (Table 2). Figure 9 shows COD concentrations over time with error bars representing the standard deviations between the triplicate chambers. Figure 10 shows the COD readings with respect to the initial COD readings, which is the percent of COD remaining. This allows the sodium azide chambers to be viewed from the same starting point as the other two chambers. The COD values for soil only and lupine chambers decreased similarly (Figures 9 and 10). From days 0 to 18, they decreased rapidly from approximately $100 \mathrm{mg} \mathrm{COD} / \mathrm{L}$ to 50 $\mathrm{mg} \mathrm{COD} / \mathrm{L}$. During days 18 to 39, the COD stayed at approximately $50 \mathrm{mg} / \mathrm{L}$. The COD readings between days 54 and 105 were around $20 \mathrm{mg} / \mathrm{L}$. Similar reductions in COD were observed in the willow experiments, but this second drop in COD levels was not seen in the 105 day willow experiment (Hoffman, 2003).

Table 2 - COD Data

\begin{tabular}{|c|c|c|c|c|c|c|c|c|c|c|c|c|}
\hline \multirow[b]{3}{*}{ Day } & \multicolumn{4}{|c|}{ Lupine and Soil } & \multicolumn{4}{|c|}{ Soil Only } & \multicolumn{4}{|c|}{ Inhibited w/Sodium Azide } \\
\hline & \multirow{2}{*}{\begin{tabular}{|c|}
$\begin{array}{c}\text { Avg } \\
\text { Abs }\end{array}$ \\
$440 \mathrm{~nm}$ \\
\end{tabular}} & \multirow{2}{*}{$\begin{array}{l}\text { Std } \\
\text { Dev }\end{array}$} & \multirow{2}{*}{$\begin{array}{l}\text { Ave } \\
\text { COD } \\
\mathrm{mg} / \mathrm{L}\end{array}$} & \multirow{2}{*}{$\begin{array}{l}\text { Std } \\
\text { Dev }\end{array}$} & \multirow{2}{*}{\begin{tabular}{|c|}
$\begin{array}{c}\text { Avg } \\
\text { Abs }\end{array}$ \\
$440 \mathrm{~nm}$ \\
\end{tabular}} & \multirow{2}{*}{$\begin{array}{l}\text { Std } \\
\text { Dev }\end{array}$} & \multirow{2}{*}{$\begin{array}{l}\text { Avg } \\
\text { COD } \\
\mathrm{mg} / \mathrm{L}\end{array}$} & \multirow{2}{*}{$\begin{array}{c}\text { Std } \\
\text { Dev }\end{array}$} & \multirow{2}{*}{\begin{tabular}{|c|}
$\begin{array}{c}\text { Avg } \\
\text { Abs }\end{array}$ \\
$600 \mathrm{~nm}$ \\
\end{tabular}} & \multirow{2}{*}{$\begin{array}{l}\text { Std } \\
\text { Dev }\end{array}$} & \multirow{2}{*}{$\begin{array}{l}\text { Avg } \\
\text { COD } \\
\mathrm{mg} / \mathrm{L}\end{array}$} & \multirow{2}{*}{$\begin{array}{l}\text { Std } \\
\text { Dev }\end{array}$} \\
\hline & & & & & & & & & & & & \\
\hline 0 & 0.429 & 0.0050 & 99.5 & 2.25 & 0.428 & 0.0076 & 99.8 & 3.47 & 0.050 & 0.0021 & 183 & 7.57 \\
\hline 2 & 0.466 & 0.0049 & 82.4 & 2.22 & 0.473 & 0.0025 & 79.3 & 1.14 & 0.053 & 0.0058 & 196 & 21.0 \\
\hline 3 & 0.473 & 0.0030 & 79.5 & 1.36 & 0.467 & 0.0053 & 82.2 & 2.41 & 0.054 & 0.0072 & 197 & 26.3 \\
\hline 5 & 0.480 & 0.0058 & 76.4 & 2.65 & 0.475 & 0.0084 & 78.7 & 3.81 & 0.044 & 0.0000 & 162 & 0.00 \\
\hline 8 & 0.512 & 0.0064 & 61.7 & 2.89 & 0.510 & 0.0078 & 62.6 & 3.55 & 0.044 & 0.0006 & 163 & 2.10 \\
\hline 18 & 0.539 & 0.0149 & 49.5 & 6.77 & 0.545 & 0.0065 & 46.6 & 2.96 & 0.036 & 0.0036 & 133 & 13.1 \\
\hline 24 & 0.579 & 0.0579 & 31.3 & 26.3 & 0.543 & 0.0085 & 31.0 & 29.00 & 0.027 & 0.0025 & 102 & 9.15 \\
\hline 30 & 0.517 & 0.0557 & 59.3 & 25.3 & 0.540 & 0.0081 & 48.8 & 3.70 & 0.029 & 0.0029 & 106 & 10.5 \\
\hline 39 & 0.541 & 0.0097 & 48.5 & 4.39 & 0.547 & 0.0055 & 45.7 & 2. & 0.026 & 0.0038 & 95.5 & 13.8 \\
\hline 54 & 90 & 0.0300 & 26.2 & 13 & 5 & 0.0064 & 12.2 & 2 & 0.024 & 0.0026 & 89.4 & 9.62 \\
\hline 61 & 0.593 & 0.0146 & 24.9 & 6.63 & 0.604 & 0.0026 & 19.9 & 1.20 & 0.030 & 0.0036 & 111 & 13.1 \\
\hline 74 & 0.606 & 0.0100 & 19.1 & 4.56 & 0.600 & 0.0060 & 21.1 & 5.01 & 0.032 & 0.0015 & 120 & 5.56 \\
\hline 84 & 0.596 & 0.0185 & 23.4 & 8.40 & 0.618 & 0.0132 & 13.5 & 6.01 & 0.030 & 0.0035 & 111 & 12.6 \\
\hline 105 & 0.608 & 0.0104 & 18.2 & 4.71 & 0.586 & 0.0523 & 27.9 & 23.8 & 0.035 & 0.0035 & 131 & 12.8 \\
\hline
\end{tabular}


Figure 9 - Average COD Values Over Time

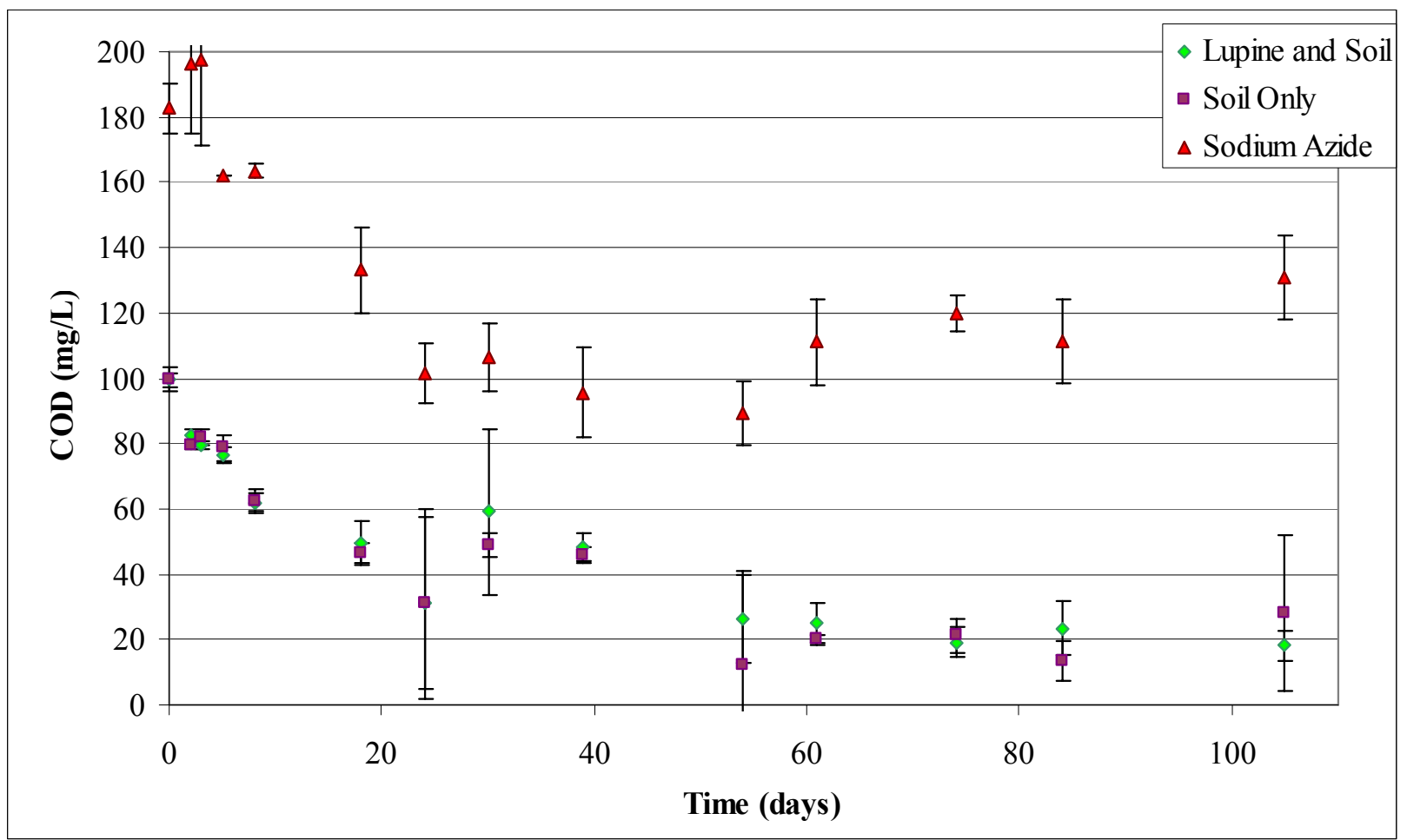

Figure 10 - Percent Initial COD Values Over Time

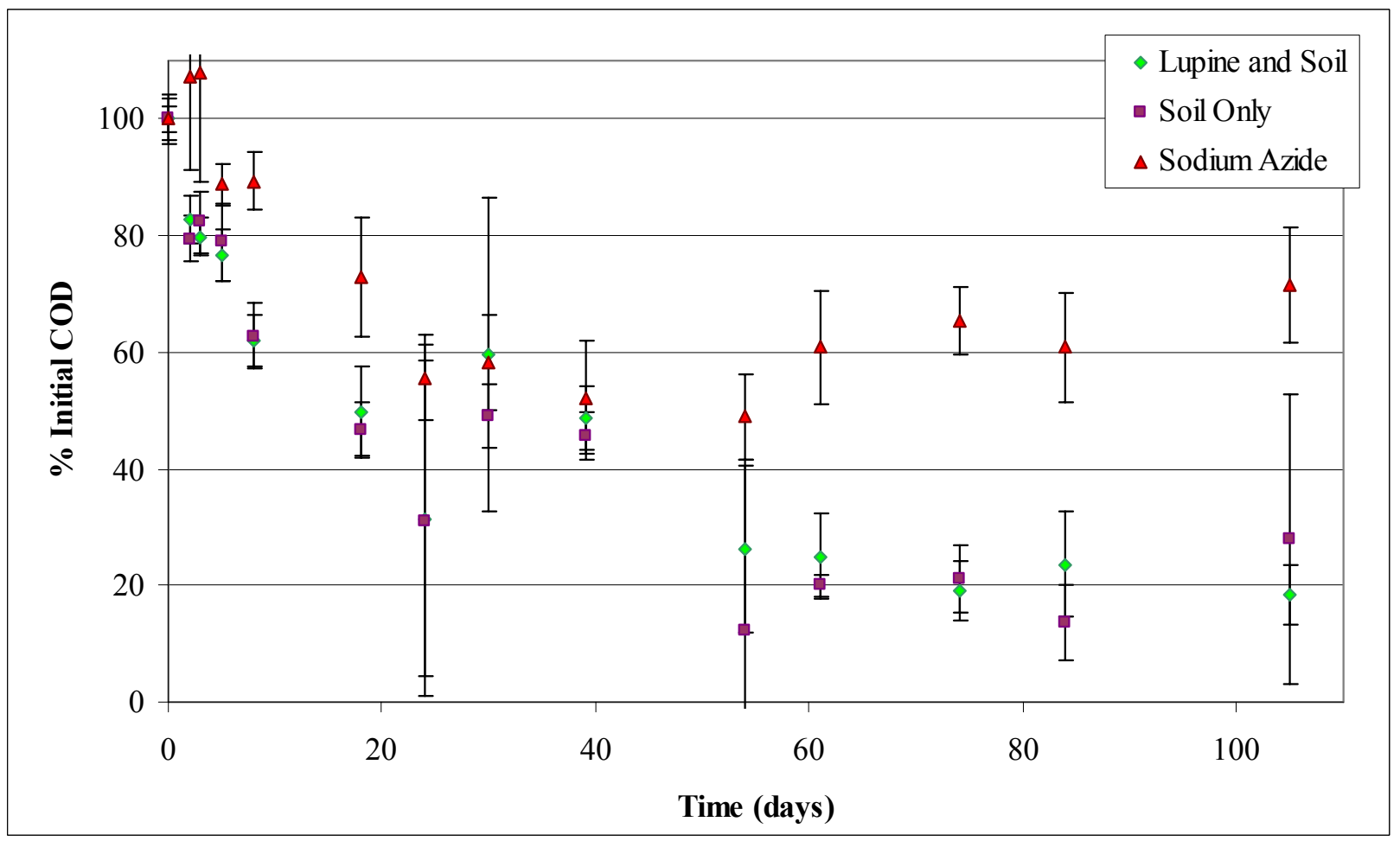


By assuming a direct relationship between TPH and COD, the kinetics of the TPH degradation can be estimated using the COD data. An initial COD drop occurred from days 0 to 18 . The initial COD drop was analyzed for zero and first order kinetics. The $\mathrm{R}^{2}$ values for all chamber sets were higher for the first order kinetics (semi-log plot) than for the zero order kinetics (linear plot). The kinetics are more likely first order than zero order. Based on the first order analysis, the degradation rate constants were 0.0365 for the plant, 0.0398 for the soil only, and 0.0211 day $^{-}$ ${ }^{1}$ for the sodium azide chambers. The first order rate constant for soil only chambers is similar to the $0.0386 \mathrm{day}^{-1}$ found by Hoffman (2003). The first order rate constant was lower for the vegetated chambers $\left(0.0305\right.$ day $\left.^{-1}\right)$ in the 105 -day willow experiment (Hoffman, 2003) than for the lupine chambers $\left(0.0365\right.$ day $\left.^{-1}\right)$. The sodium azide rate constant was lower in the 105-day willow experiment (Hoffman, 2003) at $0.0087 \mathrm{day}^{-1}$, probably due to the higher concentration of sodium azide used. At 24 days the average percentages of initial COD remaining were $31 \%$ for the soil only, $31 \%$ for the lupine, and $56 \%$ for the sodium azide chambers. For TPH at 24 days, the percent initial TPH remaining were $28.7 \%$ for the soil only, $28.1 \%$ for the lupine, and 41.6 $\%$ for the sodium azide chambers. The TPH and COD removals were similar for the soil only and plant chambers at 24 days. The sodium azide COD decreased more than did the TPH possibly due to sodium azide removal in the chambers. At 105 days the percentages of initial COD remaining were $28 \%$ for the soil only, $18 \%$ for the lupine, and $71 \%$ for the sodium azide chambers. For TPH, at 105 days the percentages of initial TPH remaining were $12.2 \%$ for the soil only, $6.1 \%$ for the plant, and $17.4 \%$ for the sodium azide chambers. The 105 day COD and TPH values do not appear to correlate.

\section{Effect of Lupines on Nutrients}

The initial nutrient concentrations in the ground water were minimal, except for sulfate. No nitrate, nitrite, or ortho phosphate was detected (Table 3). Approximately $0.8 \mathrm{mg} / \mathrm{L}$ total phosphorus as $\mathrm{P}, 1 \mathrm{mg} / \mathrm{L}$ ammonia, and $80 \mathrm{mg} / \mathrm{L}$ sulfate were detected initially (Table 3 ). After 105 days, ammonia, nitrate, nitrite, or ortho phosphate were not detected. The total phosphorus as $P$ concentrations reduced to averages of $0.43 \mathrm{mg} / \mathrm{L}$ for the soil only and $0.26 \mathrm{mg} / \mathrm{L}$ for the lupine chambers. The sulfate concentrations reduced to averages of $66 \mathrm{mg} / \mathrm{L}$ for the soil only and $56 \mathrm{mg} / \mathrm{L}$ for the lupine chambers. The differences between the soil only and lupine chambers were not significant ( $p>0.05$ for 2 -sample t-test with $95 \%$ confidence interval). The lower averages for the plant chambers may have been due to the lupines utilizing the nutrients. No increases in available nitrogen were observed for the chambers with lupines, since both ammonia and nitrate were below detection limits for these chambers at 105 days.

\section{Lupine Growth}

The growth of the lupines was monitored throughout the experiment. Lupines growing naturally at Guadalupe (Figure 11) can range from 6 to 12 inches in height after 6 to 12 months with taproots extending greater than 3 feet deep. The lupines grown in the chambers (for six months) all had one stalk with leaves growing off of it (Figure 2). The stalk did not increase in size as the experiment progressed. The plants in the lab experiment remained small throughout the 105 days. To gauge growth, individual leaves were counted four times. The average number of leaves was similar for the plants in the beginning of the experiment, but as the experiment progressed, certain plants grew faster than others. At the end of the experiment, destructive 
sampling was conducted to determine if nodules were present. Many nodules were found (Figure 12). However, the majority of these nodules were not pink inside indicating they may not have been fixing nitrogen. Further evidence of the lack of nitrogen fixation was the yellow appearance of the leaves indicating a nitrogen deficiency. Additional analysis on the nodules to determine if they were fixing nitrogen was not conducted. With more plant growth, a stronger effect on TPH degradation and/or nutrient addition may have been observed.

\section{Table 3 - Nutrient Analysis}

\begin{tabular}{|c|c|c|c|c|}
\hline & & 105 & days & \\
\hline & $\begin{array}{l}\text { Initial } \\
(\mathrm{mg} / \mathrm{L})\end{array}$ & $\begin{array}{c}\text { Soil } \\
\text { Only } \\
(\mathrm{mg} / \mathrm{L})\end{array}$ & $\begin{array}{l}\text { Lupine } \\
\& \text { Soil } \\
(\mathrm{mg} / \mathrm{L})\end{array}$ & $\begin{array}{l}\mathrm{PQL}^{1} \\
(\mathrm{mg} / \mathrm{L})\end{array}$ \\
\hline \multirow{3}{*}{ Ammonia-N } & 1.0 & $\mathrm{ND}^{2}$ & ND & 0.1 \\
\hline & 0.9 & ND & ND & 0.1 \\
\hline & $\mathrm{N} / \mathrm{A}^{3}$ & $\mathrm{~N} / \mathrm{A}$ & ND & 0.1 \\
\hline Average & 1.0 & ND & ND & \\
\hline \multirow{3}{*}{$\mathrm{NO}_{3}-\mathrm{N}$} & ND & ND & ND & 0.5 \\
\hline & ND & ND & ND & 0.5 \\
\hline & $\mathrm{N} / \mathrm{A}$ & $\mathrm{N} / \mathrm{A}$ & ND & 0.5 \\
\hline Average & ND & ND & ND & \\
\hline \multirow{3}{*}{$\mathrm{NO}_{2}-\mathrm{N}$} & ND & ND & ND & 0.5 \\
\hline & ND & ND & ND & 0.5 \\
\hline & $\mathrm{N} / \mathrm{A}$ & $\mathrm{N} / \mathrm{A}$ & ND & 0.5 \\
\hline Average & ND & ND & ND & \\
\hline \multirow{3}{*}{ Ortho Phosphate } & ND & ND & ND & 0.5 \\
\hline & ND & ND & ND & 0.5 \\
\hline & $\mathrm{N} / \mathrm{A}$ & $\mathrm{N} / \mathrm{A}$ & $\mathrm{ND}$ & 0.5 \\
\hline Average & ND & ND & ND & \\
\hline \multirow{3}{*}{ Sulfate } & 80 & 77 & 48 & 1.0 \\
\hline & 80 & 55 & 57 & 1.0 \\
\hline & $\mathrm{N} / \mathrm{A}$ & N/A & 64 & 1.0 \\
\hline Average & 80 & 66 & 56 & \\
\hline \multirow{3}{*}{ Total Phosphorus as $\mathrm{P}$} & 0.84 & 0.46 & 0.34 & 0.02 \\
\hline & 0.78 & 0.39 & 0.19 & 0.02 \\
\hline & $\mathrm{N} / \mathrm{A}$ & $\mathrm{N} / \mathrm{A}$ & 0.25 & 0.02 \\
\hline Average & 0.81 & 0.43 & 0.26 & \\
\hline \multicolumn{5}{|c|}{${ }^{1}$ PQL - Practical Quantitation Limit } \\
\hline \multicolumn{5}{|l|}{${ }^{2}$ ND - Not Detected } \\
\hline \multicolumn{5}{|l|}{${ }^{3}$ N/A - Not Applicable } \\
\hline
\end{tabular}




\section{Evaporation/Evapotranspiration}

The water loss in the reservoirs varied depending on the weather, position of the reservoirs, and type of chamber. A few times during the experiment, water circulation problems were encountered, and these problems were corrected upon discovery. The overall average evaporation rates were $27 \mathrm{~mL} /$ day for the lupine, $29 \mathrm{~mL} /$ day for the soil only, and $23 \mathrm{~mL} /$ day for the sodium azide chambers. The average cumulative water addition was significantly higher for the lupine and soil only than for the sodium azide chambers. No significant difference occurred for water addition between the plant and soil only chambers. In the willow experiment, the sodium azide inhibited and soil only chambers had similar water usage, while the willow chambers had over twice the water usage (Hoffman, 2003). In the present experiment, the lupine chambers were originally expected to use more water, but lupines are drought tolerant plants and high evapotranspiration rates would not benefit them. The placement of the experimental design may have affected the evaporation rates due to some reservoirs receiving more sun exposure.

Figure 11 - Size Perspective of Lupine Bush and Author

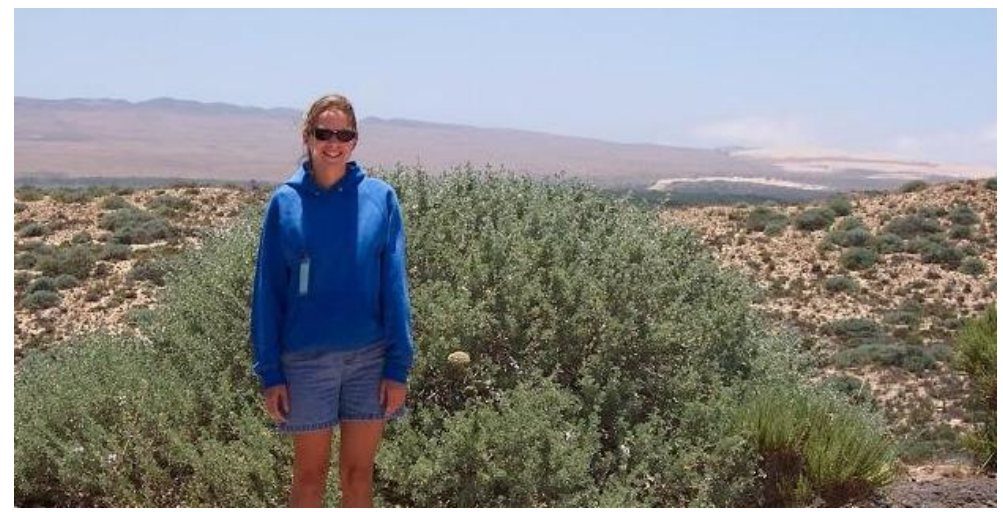

Figure 12 - Root Nodules on a Lupine Plant from this Experiment

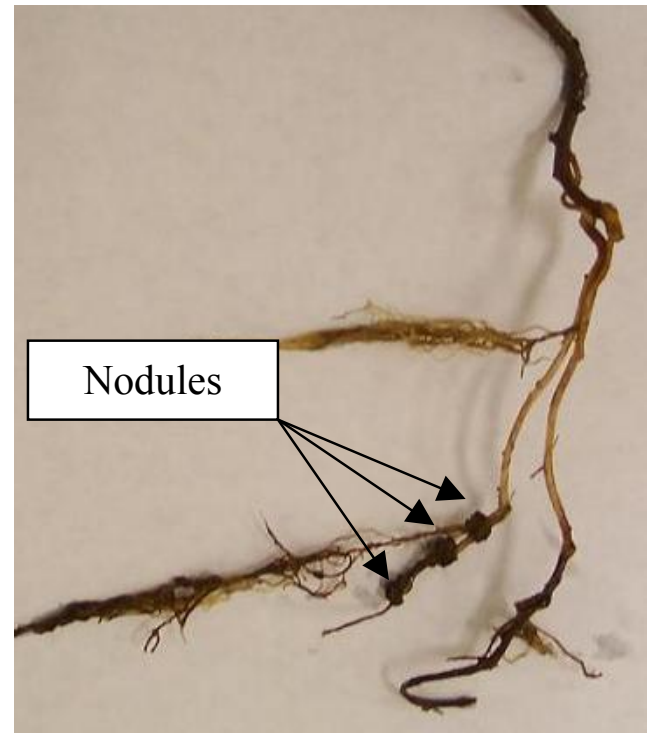




\section{Terminal Restriction Fragment (TRF) Analysis}

The microbial communities in soils at the end of the lupine experiments were assayed by TRF analysis. Based on a principle components analysis, a shift in microbial community was observed when lupines are present (Figure 13), but fewer replications yielded enough DNA for TRF analyses, and therefore the results are not statistically interpretable. The $\mathrm{x}$ and $\mathrm{y}$ axes of Figure 13 show relative abundance of the TRF fragments that comprised the majority of the variability between the samples. Chambers with soil only (Soil 1, 5, and 9) are grouped on the lower right side, indicating a different microbial community that the chamber with lupine (Lupine 2). During the lupine experiments one of the chambers was watered with only deionized water instead of diluent-contaminated groundwater (DI water no TPH), and the TRF pattern for soil from this chamber was markedly different than those in the chambers with diluent (Figure 13). In fact, this difference was greater than the effect of plants alone.

Figure 13 - Comparison of Significant TRF Peaks for Chambers with and without Lupines

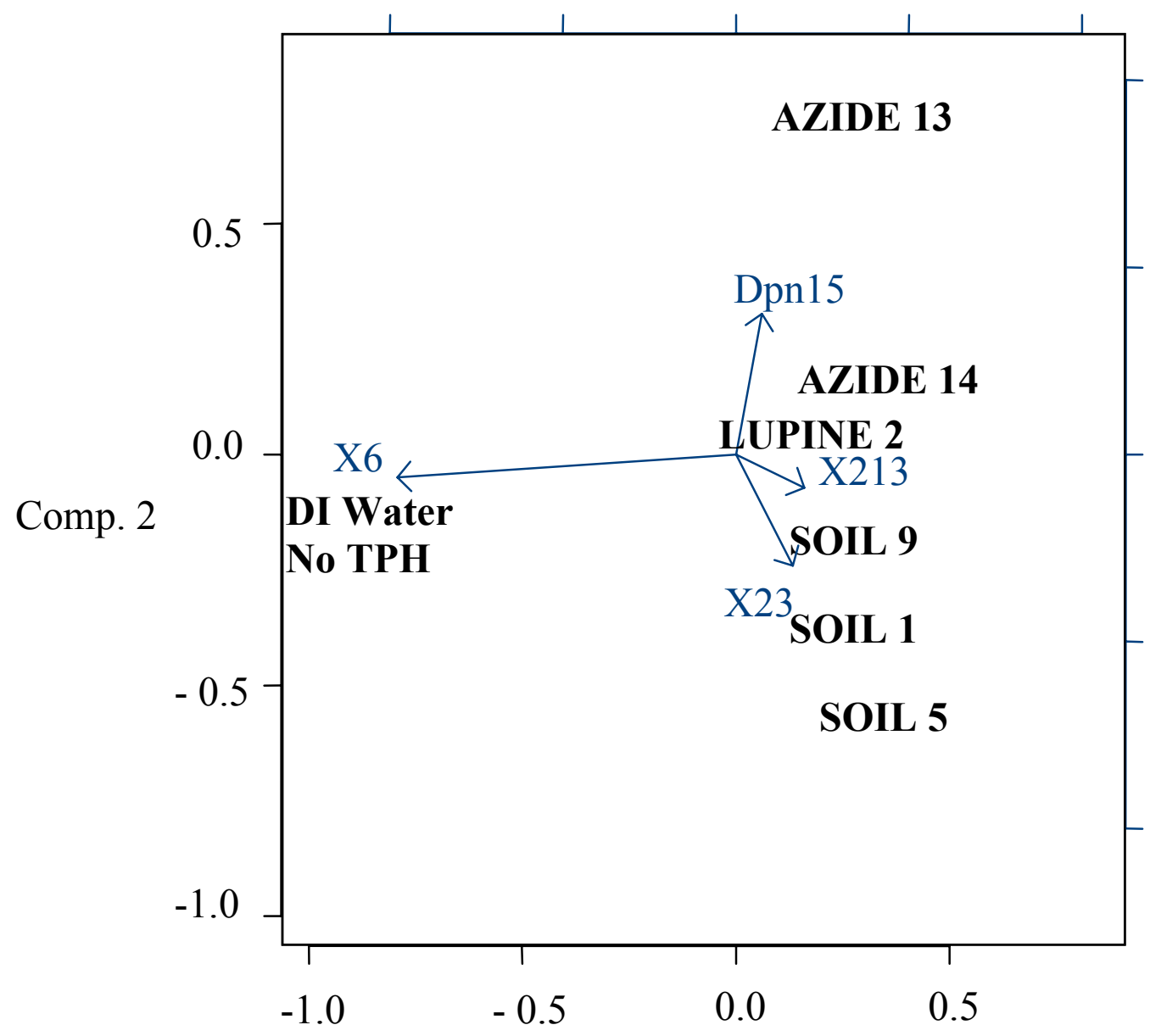

Comp. 1 


\section{CONCLUSIONS}

Over the initial 24 days, the lupines did not enhance total petroleum hydrocarbon (TPH) biodegradation, but after 105 days, the lupines had significantly increased biodegradation compared to the soil only chambers. These results are similar to the results found previously for willows (Hoffman, 2003 and Hoffman and Nelson, 2003). The lack of biodegradation enhancement at 24 days may have been due to the slow lupine growth or bacteria using exudates instead of hydrocarbons. The shorter chain hydrocarbons were removed from the groundwater more quickly than were the longer chain hydrocarbons. The lupine chambers degraded all the hydrocarbon ranges more quickly than did the soil only chambers after 105 days. The lupines in the chambers all survived the experiment, though they did not grow as large as was expected. Nodules were found on the lupine roots, but it was not definitively determined if nitrogen had been fixed. Greater plant effects might have been observed if larger plants, with more developed roots, had been established.

Limited nutrients were present in the groundwater initially and after 105 days. An insignificant decrease occurred in sulfate and total phosphorus for the plant chambers compared to the soil only chambers. Ammonia and nitrate nitrogen were below detection limits in groundwater after 105 days of re-circulating through the chambers with lupines, indicating if nitrogen was fixed in the lupines it did not result in a detectable release of nitrogen.

The chemical oxygen demand (COD) removal rates seemed to correlate to the TPH removal rates from the ground water at 24 days, but did not at 105 days. Based on COD concentrations for the first 24 days, biodegradation fit a first order model better than a zero order model. The first order rate constants were $0.0365 \mathrm{day}^{-1}$ for the lupine and $0.0398 \mathrm{day}^{-1}$ for the soil only chambers.

These results may be used to predict similar enhancement of biodegradation in the field at Guadalupe because laboratory conditions were matched to field conditions. However, the plant enhancement of biodegradation in the field may be significantly higher due to the larger plants and more developed root systems. The lupines are native plants growing abundantly at the site. Additional enhancement could be realized in the field because plants could help aerate the soil. Since all of the laboratory experiments were conducted with saturated air, this effect would not be seen in the laboratory experiments. Based on the results of this experiment and the previous willow experiments, ecoremediation at the Guadalupe is a feasible option. Phytoremediation of the groundwater may take longer than would traditional pump and treat methods. However, ecoremediation is a much more desirable option with greater long-term benefits and potentially a lower residual contaminant level than can be achieved by pump and treat technologies.

\section{ACKNOLDGEMENTS}

This project is part of a larger phytoremediation research project funded by the Unocal Corporation through the Environmental Biotechnology Institute at Cal Poly. We thank Guadalupe staff including Gonzalo Garcia, Todd Ririe, Paul Lundegard and Bob Pease. We also thank the former Cal Poly graduate students Keith Elliot and Sandy Scott, who laid the groundwork for this project and thank Chris Kittsat Cal Poly for providing the TRF analyses. 


\section{REFERENCES}

Anderson, T. A., E. A. Guthrie, and B. T. Walton (1993) Bioremediation. Environmental Science and Technology, 27, 2630-2636.

Chaîneau, C. H., J. L. Morel, and J. Oudot (2000) Biodegradation of fuel oil hydrocarbons in the rhizosphere of maize. Journal of Environmental Quality, 29, 569-578.

EBI. The Environmental Biotechnology Institute Cal Poly State University, San Luis Obispo. http://www.ebi.calpoly.edu, 2003.

Elliot, K. (2002) VOC emissions from willow trees grown on hydrocarbon-contaminated groundwater in a two-compartment growth chamber. M.S. Thesis, California Polytechnic State University, San Luis Obispo, CA.

EPA. (2000) Introduction to Phytoremediation. Cincinnati, Ohio: National Risk Management Research Laboratory.

Gladstones, J. S., C. Atkins, and J. Hamblin eds. (1998) Lupins as Crop Plants: Biology, Production and Utilization; Center for Agriculture and Biosciences International; Cambridge, United Kingdom.

Graham, P. H. and C. P. Vance (2003) Legumes: Importance and Constraints to Greater Use. Plant Physiology, 131, 872-877.

Gustafson, J., J. Griffith, and D. Orem (1997) Selection of Representative TPH Fractions Based on Fate and Transport Considerations. TPH Criteria Working Group Volume III.

Günther, T., U. Dornberger, and W. Fritshe (1996) Effects of ryegrass on biodegradation of hydrocarbons in soil. Chemosphere, 33, 203-215.

Hoffman, K. M. (2003) Phytoremediation of Hydrocarbons by Arroyo Willows in Controlled Laboratory Microcosms. M.S. Thesis, California Polytechnic State University, San Luis Obispo, CA.

Hoffman, K.M. and Y. M. Nelson (2003) Phytostimulation of hydrocarbon biodegradation by Arroyo willows in laboratory microcosms, Phytoremediation of Petroleum-contaminated Sites; Seventh International Conference on In Situ and On-Site Bioremediation; Battelle.

Lee, E. and M. K. Banks (1993) Bioremediation of petroleum contaminated soil using vegetation: A microbial study. Journal of Environmental Science and Health, 28, 21872198.

Legocki, A. B., W. M. Karlowski, J. Podkowinski, M. Sikorski, and T. Stekowski (1996) Advances in Molecular Characterization of the Yellow Lupin - Bradyrhizobium sp. (Lupinus) Symbiotic Model. NATO ASI Series, Vol. G 39. Legocki, A., H. Bothe, and A. Pühler (Editors); Biological Fixation of Nitrogen for Ecology and Sustainable Agriculture; Springer-Verlag Berlin Heidelberg.

Lundegard, P. D., and Garcia, G. F. (2001) Evolving state of ecological risk assessment at the former Guadalupe oil field, California. Society of Petroleum Engineers, SPE 68341.

Martin, Wendy (2003) Investigation of hydrocarbon phytoremediation potential of Lupinus chamissonis in laboratory microcosms. M.S. Thesis, California Polytechnic State University, San Luis Obispo, CA.

Orchard, B. J., W. J. Douchette, J. K. Chard, and B. Bugbee (2000) A novel laboratory system for determining fate of volatile organic compounds in planted systems. Environmental Toxicology and Chemistry, 19, 888-894.

Palmroth, M. R. T., J. Pichtel, and J. A. Puhakka (2002) Phytoremediation of subartic soil contaminated with diesel fuel. Bioresource Technology, 84, 221-228. 
Postgate, J. (1998) Nitrogen Fixation, 3rd ed.; Cambridge University Press; Cambridge, United Kingdom.

Schnoor, J., L. Licht, S. McCutcheon, N. Wolfe, and L. Carreira (1995) Phytoremediation of organic and nutrient contaminants. Environmental Science and Technology, 29, 318A$323 \mathrm{~A}$.

Scott, S. (2001) A laboratory model to study phytoremediation of hydrocarbon contamination using California native plants. Senior Project, California Polytechnic State University, San Luis Obispo.

Wang, M. J. and K. C. Jones (1994) Behaviour and fate of chlorobenzenes in spiked and sewage sludge-amended soil. Environmental Science and Technology, 28, 1843-1852.

Van der Lelie, D., J. P. Schwitzguebel, D. Glass, J. Vangronsveld, and A. Baker (2001) Assessing Phytoremediation's Progress in the United States and Europe. Environmental Science and Technology, 35, 446-452. 